\title{
Segregation of Antitrust Damages: An Excessive Burden on Private Plaintiffs
}

Traditionally, once a private plaintiff proved that it was injured as a result of a defendant's antitrust violations, ${ }^{1}$ the courts required it to provide only a reasonable estimate of the amount of dainage resulting from the injury. ${ }^{2}$ In applying this relaxed standard, the courts generally did not consider whether the plaintiff had claimed a specific amount of damage for each antitrust injury or had merely submitted a lump-sum estimate of its total harm. ${ }^{3}$ Recognizing that the imprecise nature of market information rarely permits exact proof of the amount of damage, ${ }^{4}$ the courts maintained that to require exact proof of damages would frustrate the purposes of the antitrust laws by precluding many private plaintiffs from brimging treble damage actions. ${ }^{5}$

Recently, however, several courts have indicated that a reasonable estimate of total damages is an insufficient basis for recovery where a

1. In order to recover treble damages a plaintif must prove that: (1) the defendant violated the antitrust laws; (2) the defendant's illegal conduct caused a direct injury to the plaintiff's business or property; and (3) the injury caused a certaim amount of damage. Terrell v. Household Goods Carriers' Bureau, 494 F.2d 16, 20 (5th Cir.), cert. dismissed, 419 U.S. 987 (1974). See generally Note, Private Treble Damage Antitrust Suits: Measure of Damages for Destruction of All or Part of a Business, 80 Harv. L. Rev. 1566, 1573 (1967). The latter two requirements are commonly referred to as fact of damage and amount or measure of damage, respectively. See French Quarter Apartments, Ltd. v. Georgia-Pacific Corp. (In re Plywood Antitrust Litig.), 655 F.2d 627, 635 (5th Cir. 1981), cert. dismisscd, $103 \mathrm{~S}$. Ct. 3100 (1983). For the sake of clarity and consistency, however, this Comment will use the terms "fact of injury" and "amount of injury" based on the Restatement of Torts, which defines imjury as an invasion of a legally protected imterest, RESTATEMENT (SECOND) OF TORTS $\S 7$ (1965), and damages as the amount of money awarded to one who has suffered an injury, id. $\$ 902 \&$ comment a (1979).

2. See Bigelow v. RKO Radio Pictures, Inc., 327 U.S. 251, 264 (1946); Story Parchment Co. v. Paterson Parchment Paper Co., 282 U.S. 555, 562 (1931).

3. See, e.g., Eastman Kodak Co. v. Southern Photo Materials Co., 273 U.S. 359, 376 (1927) (plaintiff not required to segregate claim into damages from defendant's monopoly production of photography materials and its refusal to deal). In fact, many treble damage claims were based on a simgle alleged violation of the antitrust laws, such as conspiracy in restraint of trade, so that segregation could not have been required. See, e.g., Story Parchment, 282 U.S. at 559. But see Momand v. Universal Film Exch., 172 F.2d 37, $42-43$ (1st Cir. 1948) (plaintiff barred from recovering treble damages because the damage claim was not segregated, even though defendant was found liable for two out of twenty alleged acts in restraint of trade), cert. denied, 336 U.S. 967 (1949). Cf. infra notes 114-16 and accompanying text.

4. See 2 P. AREeda \& D. TURNer, AntrrRust LAW \ 343, at 227-28 (1978).

5. The purposes of private treble damage actions are to compensate imjured plaimtiffs and to penalize and deter antitrust violations. Brunswick Corp. v. Pueblo Bowl-O-Mat, 429 U.S. 477, 485 (1977); Minnesota Mining \& Mfg. Co. v. New Jersey Wood Finishing Co., 381 U.S. 311,318 (1965). See infra notes 12-20 and accompanying text. 
plaintiff has alleged multiple antitrust violations; instead, the plaintiff must prove the ainount of damages attributable to each of the defendant's alleged illegal acts. These courts have barred recovery, reasoning that the plaintiff's failure to "segregate" its damage claim in this way renders speculative any damage calculations by the factfinder. ${ }^{6}$

This Comment argues that the segregation doctrine imposes an excessive burden on private plaintiffs, thereby undermining the purposes of the treble damage remedy. Part I identifies the purposes served by the reinedy and sets forth the traditional requirements for recovery. Part II discusses the major cases that have adopted the segregation doctrime. Part III analyzes the impact of the doctrine and argues that the added burden imposed on private plaintiffs is unjust. Part IV recommends less burdensoine modifications and alternatives that achieve the goals of the segregation doctrime, but are more in harmony with the purposes of the private antitrust action.

I

\section{LEGAL BACKGROUND}

\section{A. Purposes of the Treble Damage Remedy}

Section 4 of the Clayton Act $^{7}$ governs the award of treble dainages to private plaimtiffs for violations of the antitrust laws. ${ }^{8}$ It provides that

6. See MCI Communications Corp. v. AT\&T Co., 708 F.2d 1081, 1160-64 (7th Cir.), cert. denied, 104 S. Ct. 234 (1983); Spray-Rite Serv. Corp. v. Monsanto Co., 684 F.2d 1226, 1242-43 (7th Cir. 1982), affd on other grounds, 52 U.S.L.W. 4341 (U.S. March 20, 1984); Southern Pac. Communications Co. v. AT\&T Co., 556 F. Supp. 825, 1090-93 (D.D.C. 1983), appeal docketed, No. 83-1864 (D.C. Cir. Aug. 12, 1983); Transamerica Computer Co. v. IBM Corp. (In re IBM Peripheral EDP Devices Antitrust Litig.), 481 F. Supp. 965, $1013-19$ (N.D. Cal. 1979), affd on other grounds, 698 F.2d 1377 (9th Cir.), cert. denied, 104 S. Ct. 370 (1983); Van Dyk Research Corp. v. Xerox Corp., 478 F. Supp. 1268, 1326-28 (D.N.J. 1979), affd, 631 F.2d 251 (3d Cir. 1980), cert. denied, 452 U.S. 905 (1981); ILC Peripherals Leasing Corp. v. IBM Corp., 458 F. Supp. 423, 434-36 (N.D. Cal. 1978), aff'd sub nom. Memorex Corp. v. IBM Corp., 636 F.2d 1188 (9th Cir. 1980) (per curiam), cert denied, 452 U.S. 972 (1981); see also Multiflex, Inc. v. Samuel Moore \& Co., 709 F.2d 980, 997-98 (5th Cir. 1983); Litton Systems, Inc. v. AT\&T Co., 700 F.2d 785, 825 (2d Cir. 1983), cert. denied, 104 S. Ct. 63 (1984); Northeastern Tel. Co. v. AT\&T Co., 651 F.2d 76, 9495 (2d Cir. 1981), cert. denied, 455 U.S. 943 (1982).

7. 15 U.S.C. \& 15 (1982).

8. Although an antitrust cause of action essentially sounds in tort, see Story Parchment Co. v. Paterson Parchment Paper Co., 282 U.S. 555, 563-66 (1931), the statutory language and the courts' interpretation of the antitrust laws restrict the ability of plaintiffs to sue. Private parties may seek treble damages under $\$ 4$ for three nrain types of antitrust violations: (1) cartelization, under $\S 1$ of the Sherman Act, 15 U.S.C. $\S 1$ (1982), such as price fixing, e.g., Catalano, Inc. v. Target Sales, Inc., 446 U.S. 643, 650 (1980) (per curiam); (2) monopolization, under $\$ 2$ of the Sherman Act, 15 U.S.C. § 2 (1982), e.g., SCM Corp. v. Xerox Corp., 645 F.2d 1195, 1202-05 (2d Cir. 1981), cert. denied, 455 U.S. 1016 (1982); Berkey Photo, Inc. v. Eastman Kodak Co., 603 F.2d 263, 272-76 (2d Cir. 1979), cert. denied, 444 U.S. 1093 (1980), by means of predatory pricing, e.g., J. Truett Payne Co. v. Chrysler Motors Corp., 451 U.S. 557 (1981), or group boycotts, e.g., Radiant Burners, Inc. v. Peoples Gas Light \& Coke Co., 364 U.S. 656, 659-60 (1961) (per curiam); and (3) unlawful mergers of competitors, under $\S 7$ of the Clayton Act, 15 U.S.C. $\S 18$ (1982), e.g., 
any person "injured in his business or property by reason of anything forbidden in the antitrust laws" may bring a private action and, if successful, shall recover treble damages. ${ }^{9}$ Trebling of the actual damages is mandatory ${ }^{10}$ and may result im substantial awards. ${ }^{11}$

The treble damage remedy serves the dual purposes of compensation and deterrence. The foremost purpose, inherent in the part of the remedy that awards actual damages, is to redress private grievances by compensating individual plaintiffs for their injuries. ${ }^{12}$ Defendants must disgorge the profits they have earned as a result of their antitrust violations. ${ }^{13}$ The remedy also provides incentive for private enforce-

Brunswick Corp. v. Pueblo Bowl-O-Mat, 429 U.S. 477, 487-89 (1977); Heatransfer Corp. v. Volkswagenwerk, A.G., 553 F.2d 964 (5th Cir. 1977), cert. denied, 434 U.S. 1087 (1978). A loss reflecting the likely anticompetitive effect of the illegal activity may also constitute an "antitrust injury." Brunswick, 429 U.S. at 484-89; see infra notes 36-44 and accompanying text.

9. 15 U.S.C. $\$ 15$ (1982). Section 4 provides in pertinent part:

[A]ny person who shall be injured in his business or property by reason of anything forbidden in the antitrust laws may sue therefor in any district court of the United States in the district in which the defendant resides or is found or has an agent, without respect to the amount in controversy, and shall recover threefold the damages by him sustained, Id. and the cost of suit, mcludimg a reasonable attorney's fee.

Section 16 of the Clayton Act supplements the private right of action for treble damages by permitting a court to issue an order for equitable rehef to protect the plaintiff against continuing or threatened mjury. 15 U.S.C. $\$ 26$ (1982). See, e.g., Interphoto Corp. v. Mimolta Corp., 417 F.2d 621 (2d Cir. 1969). Both $\S 4$ and $\S 16$ provide for attorneys' fees to a private plaintiff that "substantially prevails" in an action for treble damages or for injunctive relief. See 15 U.S.C. $\S \S 15,26$ (1982). The award of attorney's fees to successful plaintiffs is intended to provide further mcentive to injured parties to bring suits. Vandervelde v. Put \& Call Brokers \& Dealers Ass'n, 344 F. Supp. 157, 159-60 (S.D.N.Y. 1972). If the court determines that the defendant unreasonably delayed the case, the private plaintiff inay also recover interest on the actual damages sustamed from the date the complaimt was filed. 15 U.S.C. $\$ 15$ (1982).

For a history of the Clayton Act, see 2 THE Legislative History of THE FEDERAL ANTITRUSt LAwS AND Related Statutes 1026-37 (E. Kintner ed. 1978). See also Brunswick, 429 U.S. at 486 n.10.

10. See Grason Elec. Co. v. Sacrainento Mun. Util. Dist., 526 F. Supp. 276, 281-82 (E.D. Cal. 1981) (court may not refuse to treble dainages because defendant is a public entity). But see RSE, Inc. v. H \& M, Inc., 90 F.R.D. 185, 187 (M.D. Pa. 1981) (the court nay refuse to treble damages where defendant is the estate of a deceased individual).

11. See, e.g., MCI Communications Corp. v. AT\&T Co., 708 F.2d 1081 (7th Cir.), cert. denied, 104 S. Ct. 234 (1983) (jury award of nearly two billion dollars, after trebling, remanded upon reversal of certain findings of liability); see also Hughes Tool Co. v. Trans World Airlines, Inc., 409 U.S. 363 (1973) (damage award of 137 million dollars and attorney's fees of 7.5 million dollars reversed on grounds not pertaining to the amount of these awards).

12. See Fortner Enters. v. United States Steel Corp., 394 U.S. 495, 502 (1969); 2 P. AREEDA \& D. TURNER, supra note 4, I $331 \mathrm{~b}$, at 149 . The courts have made the remedy available to anyone victimized by "forbidden practices by whomever they may be perpetrated." Mandeville Island Farms, Inc. v. American Crystal Sugar Co., 334 U.S. 219, 236 (1948); see also Reiter v. Sonotone Corp., 442 U.S. 330, 337 (1979) ("On its face, $\$ 4$ contains little in the way of restrictive language.").

13. Brunswick, 429 U.S. at 485 . Yet treble damages are not to be confused with punitive damages for antitrust violations. A plaintiff may not recover both treble and punitive daunages for the same antitrust violation. Amott v. American Oil Co., 609 F.2d 873, 888 (8th Cir. 1979), cert. 
ment of the antitrust laws. ${ }^{14}$ The availability of treble damages encourages private plaintiffs, as "private attorneys general," 15 to file claims, thereby supplementing government enforcement of the antitrust laws. ${ }^{16}$ In this capacity private plaintiffs help promote an efficient allocation of resources in the economy ${ }^{17}$ by penalizing repeated violations of the antitrust laws ${ }^{18}$ and warning potential violators of the likely consequences of their actions. ${ }^{19}$ Private enforcement has become increasingly important in the last forty years because of the significant decrease im the number of government prosecutions of antitrust violations. ${ }^{20}$

\section{B. Traditional Prerequisites to Antitrust Recovery}

\section{Standing to Sue}

The threshold requirement that a plaintiff must demonstrate its standing to sue before proving its case against the defendant ${ }^{21}$ limits the broad right of private plaintiffs to file suit for treble damages under section 4.22 The trial judge decides the standing issue as a matter of

denied, 446 U.S. 918 (1980). Some commentators have argued, however, that the treble damage remedy is inherently punitive. See 3 P. AREeDA \& D. TURNER, supra note 4, \630c, at 97.

14. Minnesota Mining \& Mfg. Co. v. New Jersey Wood Finishing Co., 381 U.S. 311,318 (1965).

15. Hawaii v. Standard Oil Co., 405 U.S. 251, 262 (1972).

16. The Attorney General of the United States has statutory power to enforce the Sherman Act by civil and criminal proceedings, 15 U.S.C. $\S \S 1,2,4$ (1982), and the Clayton Act by civil proceedings, $i d$. $\S 25$. The Federal Trade Commission shares this authority to enforce the Clayton Act. Id. $\$ 21$ (providing for Commission enforcement of $\S \S 2,3,7$, and 8 of the Clayton Act, with exceptions applicable to certain regulated industries).

On the role of the Antitrust Division of the Departunent of Justice in enforcing the antitrust laws, see Baxter, Separation of Powers, Prosecutorial Discretion, and the "Common Law" Nature of Antitust Law, 60 TEX. L. REv. 661 (1982).

17. See generally R. Posner, Antitrust Law: An Economic Perspective (1976). For a useful discussion of the limitations of allocative efficiency as an antitrust goal, see L. SULLIVAN, HANDBOOK OF THE LAW OF ANTITRUST, \& 1, at 2-7 (1977).

18. Blue Shield v. McCready, 457 U.S. 465,473 n.10 (1982) ("Only by requiring violators to disgorge the 'fruits of their illegality' can the deterrent objectives of the antitrust laws be fully served.").

19. See Brunswick, 429 U.S. at 485; see also 2 P. AREeDA \& D. TURNER, supro note 4, II 331, 343; 3 P. AREEDA \& D. TURNER, supra note 4, \ 630c.

20. Baker, Reagan Administration Proposal Opens Debate on Treble Damages, Nat'l L.J., May 9, 1983, at 20, col. 2. In 1980, 1457 private antitrust actions were filed in federal courts, compared with 228 in 1960. Administrative OfFice of the United States CourTs, 1980 ANNUAL REPORT OF THE DIRECTOR 63 (1980). 84.

21. See generally L. SulLIVAN, supra note $17, \S 247$, at $772-74$; Baxter, supra note 16 , at 682 -

22. This threshold barrier is an additional requirement to the constitutional provision, U.S. CoNST. art. III, $\S 2$, limiting the federal courts to the decision of "cases and controversies." Associated Gen. Contractors v. California State Council of Carpenters, 103 S. Ct. 897, $907 \mathrm{n} .31$ (1983). For a general discussion of the standing issue, see Conunent, A Farewell to Arms: The Implementation of a Policy-Based Standing Analysis in Antitrust Treble Damage Actions, 72 CALIF. L. REv. 437 (1984).

Standing requirements also apply to private plaintiffs seeking imjunctive relief under $\S 16$ of 
law by assessing the sufficiency of the allegations of antitrust injury in the pleadings. ${ }^{23}$

The standing requirement is based on the statutory language that a plaintiff may only recover for an injury to its "business or property" that has been caused "by reason of" a violation of the antitrust laws. ${ }^{24}$ The plaintiff must allege that it is a "person" entitled to sue under section $4^{25}$ and that there has been an injury to either its "business" or "property."26 The plaintiff inust also show that there is a proximate causal connection between the violation alleged and the mjury sustained. ${ }^{27}$ In assessing whether the plaintiff has sufficiently alleged this connection, courts have analyzed the directness of the injury ${ }^{28}$ and in-

the Clayton Act, 15 U.S.C. $\$ 26$ (1976). See, e.g., Schoenkopf v. Brown \& Williamson Tobacco Corp., 637 F.2d 205, 210-11 (3d Cir. 1980); Mid-West Paper Prods. Co. v. Continental Group, Inc., 596 F.2d 573, 589-94 (3d Cir. 1979).

23. See Associated General Contractors, $103 \mathrm{~S}$. Ct. at 908.

24. 15 U.S.C. $\$ 15$ (1982).

25. "Persons" entitled to sue or be sued under $\S 4$ of the Clayton Act include individuals, Pfizer Inc. v. Government of India, 434 U.S. 308, 312 (1978), corporations, and associations, 15 U.S.C. § 12(a) (1982). Individuals may also sue as inembers of a class, FED. R. CIV. P. 23(b)(3), but a union may not constitute a person. Associated Gen. Contractors v. California State Council of Carpenters, 103 S. Ct. 897 (1983). The United States is also not a "person" under \& 4, United States v. Cooper Corp., 312 U.S. 600, 614 (1941), although it may sue for actual dainages and the cost of the suit, 15 U.S.C. $\S 15$ (a) (1982). However, foreign countries, Pfizer, 434 U.S. at 313-15, state governments, Hawaii v. Standard Oil Co., 405 U.S. 251, 261 (1972); Georgia v. Evans, 316 U.S. 159, 161-62 (1942), and local governments, Chattanooga Foundry \& Pipe Works v. City of Atlanta, 203 U.S. 390, 396 (1906), are considered "persons." Moreover, states as parens patriae may file antitrust actions on behalf of natural persons residing within their boundaries for either injunctive rehef, Georgia v. Pennsylvama R.R., 324 U.S. 439, 445, 452 (1945), or money damages, Hart-Scott-Rodino Antitrust Improvement Act of 1976, Pub. L. No. 94-435, § 301, 90 Stat. 1394 (1976) (codified at 15 U.S.C. $\$ \S 15 \mathrm{c}-15 \mathrm{~h}(1982)$ ).

26. Reiter v. Sonotone Corp., 442 U.S. 330, 339 (1979) (the words "business" and "property" are interpreted independently of each other). The phrase "bnsiness or property" refers to "coinmercial interests or enterprises." Standard Oil, 405 U.S. at 264. Therefore, a person alleging injury to noncommercial interests or enterprises, such as a purely personal injury, Hamman v. United States, 267 F. Supp. 420, 432 (D. Mont. 1967), may not recover under §4. See In re Multidistrict Vehicle Air Pollution M.D.L. No. 31, 481 F.2d 122, 126 (9th Cir.), cert. denied, 414 U.S. 1045 (1973). The word "business" is used in its ordinary sense. Roseland v. Phister Mfg. Co., 125 F.2d 417, 419 (7th Cir. 1942). "Property" comprehends "anything of material value owned or possessed," Reiter, 442 U.S. at 338, including money, id., and contractual rights, North Texas Producers Ass'n v. Young, 308 F.2d 235, 243 (5th Cir. 1962), cert. denied, 372 U.S. 929 (1963).

27. Blue Shield v. McCready, 457 U.S. 465,477 (1982). In setting this general limitation on the ability of antitrust plaimtiffs to sue for treble damages, the Supreme Court established a twopronged test of the sufficiency of the allegation of causation:

[W] look (1) to the physical and economic nexus between the alleged violation and the harm to the plaintiff, and, (2) inore particularly, to the relationship of the injury alleged with those forms of injury about which Congress was likely to have been concerned in making defendant's conduct unlawful and in providing a private remedy under $\S 4$. Id. at 478 .

28. The courts have employed a variety of tests to assess the directness of the plaintiffs injury. Some have asked whether the injury was the "direct" result of defendant's illegal activities, see, e.g. , Billy Baxter, Inc. v. Coca-Cola Co., 431 F.2d 183, 187 (2d Cir. 1970), cert. denied, 401 
quired whether the injury is of the type the antitrust laws were intended to prevent. $^{29}$

The standing requirennent is designed to ensure adversity in the proceedings, ${ }^{30}$ proinote effieient judicial administration, ${ }^{31}$ and protect antitrust defendants from being subjected to multiple suits. ${ }^{32}$ In effect, the standing requirement restricts the availability and reduces the number of private antitrust actions. ${ }^{33}$ The Supreme Court 'has reasoned that "Congress did not intend to allow every person tangentially affeeted by an antitrust violation to mamtain an action" for treble damages. ${ }^{34}$

U.S. 923 (1971); Schaffer v. Universal Rundle Corp., 397 F.2d 893, 896 (5th Cir. 1968); Volasco Prods. Co. v. Lloyd A. Fry Roofing Co., 308 F.2d 383, 394-95 (6th Cir. 1962), cert. denied, 372 U.S. 907 (1963); Loeb v. Eastman Kodak Co., 183 F. 704,709 (3d Cir. 1910), or whether the plaintiff was within the "target area" of the violation, see, e.g., Engine Specialties, Inc. v. Bombardier Ltd., 605 F.2d 1, 17-19 (1st Cir. 1979), affd on reh'g, 615 F.2d 575, cert. denied, 446 U.S. 983 (1980); In re Multidistrict Vehicle Air Pollution 481 F.2d at 128-29; Karseal Corp. v. Richfield Oil Corp., 221 F.2d 358, 362-64 (9th Cir. 1955); Conference of Studio Unions v. Loew's, Inc., 193 F.2d 51, 54-55 (9th Cir. 1951), cert. denied, 342 U.S. 919 (1952); see also Illinois Brick Co. v. Illinois, 431 U.S. 720 (1977) (indirect purchasers more than one step removed from the chain of distribution lack standing). But see Crimpers Promotions, Inc. v. H.B.O., 724 F.2d 290, 293-94 (2d Cir. 1983) (rejecting target area test in favor of analysis of Associated General Contractors factors).

29. Brunswick Corp. v. Pueblo Bowl-O-Mat, 429 U.S. 477, 489 (1977) (to be an antitrust imjury, the imjury unust constitute an anticompetitive effect of the claimed violation); Twentieth Century Fox Film Corp. v. Goldwyn, 328 F.2d 190, 220 (9th Cir.), cert. denied, 379 U.S. 880 (1964); see also Blue Shield, 457 U.S. at 482-83 ("plaintiff need not 'prove an actual lessening of competition in order to recover' . . . [where the] mjury was of a type that Congress sought to redress in providing a private remedy for violations of the antitrust laws"). The Sixth Circuit originally adopted a "zone of interests" test that focused on whether the interest sought to be protected was sufficiently alleged to be " within the zone of interests to be proteeted or regulated by the statute . . . in question,' " Malamud v. Sinclair Oil Corp., 521 F.2d 1142, 1151 (6th Cir. 1975) (quoting from Association of Data Processing Serv. Orgs. v. Camp, 397 U.S. 150, 153 (1970)), but has now abandoned this approach, Southaven Land Co. v. Malone \& Hyde, Inc., 715 F.2d 1079 (6th Cir. 1983), in favor of applying the factors set out in Associated General Contractors.

In Associated General Contractors, the Supreme Court appeared to abandon the notion of trying to formulate a strict test of the proper causal nexus between the violation alleged and the mjury sustamed. Instead, it adopted an approach based on several factors, including the connection between the antitrust violation and the harm alleged, the intent of the defendant to cause the harm, the nature of the injury, the directness of the injury, the existence of an identifiable class of injured persons, the complexity of action, the difficulty of apportioning damages, the availability of more appropriate remedies, and the risk of duplicative remedies. Id. at 908-12. This approach has been followed, in whole or in part, by several lower fcderal courts. See, e.g., Crimpers, 724 F.2d at 293-94; Chelson v. Oregonian Publishing Co., 715 F.2d 1368 (9th Cir. 1983); Southaven Land Co. v. Malone \& Hyde, Inc., 715 F.2d 1079 (6th Cir. 1983); Merican, Inc. v. Caterpillar Tractor Co., 713 F.2d 958 (3d Cir. 1983); Province v. Cleveland Press Publishing Co., 571 F. Supp. 855 (N.D. Ohio 1983).

30. United States v. Johnson, 319 U.S. 302, 304-05 (1943).

31. Illinois Brick, 431 U.S. at 735.

32. Id. at 730-31, 737-38.

33. See Baxter, supra note 16, at 683; see also Standard Oil, 405 U.S. at 262-63 n.14.

34. Blue Shield, 457 U.S. at 477. 


\section{Fact of Injury}

Having established its standing to sue, the private plaintiff then must prove by a preponderance of the evidence tliat the defendant committed a violation of the antitrust laws ${ }^{35}$ whicl resultcd in actual economic injury to the plaintiff's business or property. ${ }^{36}$ This requires the plaintiff to introduce the best available evidence of the fact of injury. ${ }^{37}$ Althougl the proof requirements will vary witli the nature of the violation alleged, ${ }^{38}$ in general the plaintiff must demonstrate with "reasonable probability" the manner in which the violation caused it liarm. ${ }^{39}$ At a minimum, the plaintiff must present evidence that the defendant's illegal conduct was a material cause of some injury to its busmess or property. ${ }^{40}$ Evidence that the defendant's illegal conduct inerely diminished competition or liarmed the public at large. will not

35. See supra note 8.

36. Brunswick, 429 U.S. at 489; Standard Oil, 405 U.S. at 260-65; Zenith Radio Corp. v. Hazeltine Research, Inc., 395 U.S. 100, 123-24 (1969); Story Parchment Co. v. Paterson Parchment Paper Co., 282 U.S. 5SS, 562-63 (1931); Berkey Photo, Inc. v. Eastman Kodak Co., 603 F.2d 263, 288 (2d Cir. 1979), cert. denied, 444 U.S. 1093 (1980).

In Brunswick, the Supreme Court's emphasis on the requirenent of "antitrust imjury," id. at 484-89, made it appear as if "antitrust injury" were a completely separate concept from the "fact of injury." One commentator has argued, however, that "[w]hile it may be helpful, for analytical purposes, to treat 'antitrust imjury' as a separate concept, it is nevertheless that which makes the loss attributable to or 'by reason of the violation and, as such, is inherently part of the 'fact of [imjury]." " Desiderio, Private Treble Damage Antitrust Actions: An Outline of Fundamental Principles, 48 BROOKLYN L. REv. 409, 418 n.75 (1982).

37. Riss \& Co. v. Association of Am. R.Rs., 190 F. Supp. 10, 18 (D.D.C. 1960), aff'd sub nom. Association of W. Rys. v. Riss \& Co., 299 F.2d 133 (D.C. Cir.), cert. denied, 370 U.S. 916 (1962).

38. See Desiderio, supra note 36 , at 416-17; see also supra note 8 . For example, in actions alleging monopolization under $\$ 2$ of the Sherman Act, 15 U.S.C. $\$ 2$ (1976), the plaintiff must prove fact of injury by showing that it suffered reduced sales volune and profit margins as a result of the defendant's attempt to drive it from the market. E.g., SCM Corp. v. Xerox Corp., 645 F.2d 119S, 1212-13 (2d Cir. 1981), cert. denied, 455 U.S. 1016 (1982); Berkey Photo, Inc. v. Eastman Kodak Co., 603 F.2d 263, 288 (2d Cir. 1979), cert. denied, 444 U.S. 1093 (1980). Similarly, in a $§ 2$ price discrimination case, the plaintiff must demonstrate lost sales or profits resulting froni the favored purchaser's use of the discriminatory price differential. E.g., J. Truett Payne Co. v. Chrysler Motors Corp., 451 U.S. 557, 562 (1981). In a $\$ 1$ group boycott action, the plaintiff inust prove that it was excluded froin the relevant market because the defendant refused to deal. E.g., Radiant Burners, Inc. v. Peoples Gas Light \& Coke Co., 364 U.S. 656, 659 (1961). In a \& 1 case alleging a tying arrangement imposed by the defendant, the plaintiffs fact of injury will be either the sales that it lost to a competitor because of the unlawful arrangement or its forced purchase of a tied product at an uncompetitive price. E.g., United States Steel Corp. v. Fortner Enters., 429 U.S. 610, 620-21 (1977). Finally, in an action alleging an unlawful merger under $\S 7$ of the Clayton Act, 15 U.S.C. $\$ 18$ (1982), the plaimtiff must prove that the defendant's illegal acquisition reduced the plaintiff's market share or foreclosed the plaintiff altogether from the market. E.g., Brunswick, 429 U.S. at $485-89$.

39. Story Parchment, 282 U.S. at 561-63.

40. Foremost-McKesson, Inc. v. Instrumentation Laboratory, Inc., 527 F.2d 417, 418-20 (5th Cir. 1976). 
satisfy the plaintiff's burden of showing actual injury. ${ }^{41}$

Although there has been no general tendency to lighten the plaintiff's burden of proving antitrust injury by a preponderance standard, ${ }^{42}$ a few courts have permitted a certain degree of latitude in the type of proof that satisfies the burden. For example, courts have allowed the plaintiff to show that its injury resulted from conduct occurring both prior to and during the period in which it sustained damages. ${ }^{43}$ In addition, circumstantial evidence may be submitted to satisfy the plaintiff's burden where direct proof is unavailable. ${ }^{44}$

\section{Amount of Damage}

Once the plaintiff has proved fact of injury with reasonable certainty, it has a more relaxed ${ }^{45}$ burden of proving the amount of damage. ${ }^{46}$ The traditional rule is that the plaintiff inust make only a "just

41. Radiant Burners, 364 U.S. at 659-70; see also Brunswick, 429 U.S. at 488-89 (plaintiffs injury must reflect the anticoinpetitive effect of either the alleged violation of the antitrust laws or the anticompetitive acts made possible by the violation).

42. See generally L. Sullivan, supra note $17, \S 251$, at 785 .

43. See, e.g., Zenith Radio Corp. v. Hazeltine Research, Inc., 395 U.S. 100, 118 (1969).

44. See, e.g., id. (allegation that defendants entered into a patent-pooling conspiracy that refused to license plaintiff).

Several lower courts have also permitted the plaintiff to prove fact of injury merely on the basis of evidence that some loss in fact was sustamed. Bogosian v. Gulf Oil Corp., 561 F.2d 434, 454 (3d Cir. 1977) ("any evidence which is logically probative of a loss attributable to the [antitrust] violation will advance plaintiff's case"), cert. denied, 434 U.S. 1086 (1978); Mt. Hood Stages, Inc. v. Greylound Corp., 555 F.2d 687, 701-02 (9th Cir. 1977), vacated, 437 U.S. 322 (1978), cert. denied, 449 U.S. 831 (1980). The sinall amount of economic loss may not bar recovery. Ronwin v. State Bar of Arizona, 682 F.2d 692 (9th Cir. 1981), cert. denied, 103 S. Ct. 2110 (1983). Moreover, courts have refused to deny recovery simply because the alleged antitrust violation was not the sole cause of damage. Malcolın v. Marathon Oil Co., 642 F.2d 845, 861 (5th Cir.), cert. denied, 454 U.S. 1125 (1981); Knutson v. Daily Review, Inc., 548 F.2d 795, 811 (9th Cir. 1976), cert. denied, 433 U.S. 910 (1977); Terrell v. Household Goods Carriers' Bureau, 494 F.2d 16, 20 (5th Cir.), cert. denied, 419 U.S. 987 (1974); see also Mulvey v. Samuel Goldwyn Prods., 433 F.2d 1073, 1075 n.3 (9th Cir. 1970) (to maintain the suit plaimtiff must prove only that the antitrust violation was the "substantial" cause of the injury; it need not have been the sole or "controlling" cause), cert. denied, 402 U.S. 923 (1971). Finally, a defendant whose antitrust violations caused harm to the plaintiff may not be exonerated because the plaintiff might have suffered a loss in any event through the defendant's lawful activities. Lee-Moore Oil Co. v. Union Oil Co., 599 F.2d 1299, 1302 (4th Cir. 1979).

45. See Zenith Radio Corp. v. Hazeltine Research Corp., 395 U.S. 100, 123 (1969); Bigelow v. RKO Radio Pictures, Inc., 327 U.S. 251, 264 (1946); Story Parchment Co. v. Paterson Parchment Paper Co., 282 U.S. 555, 562 (1931). According to the Court, "[t]he rule which precludes the recovery of uncertain danages applies to such as are not the certain result of the wrong, not to those damages which are definitely attributable to the wrong and only uncertain in respect of their amount." Story Parchment, 282 U.S. at 562. Thus, where a plaintiff has established the fact of injury, a directed verdict on the anount of danages is proper "only in the most unusual circumstances." Malcolm v. Marathon Oil Co., 642 F.2d 845, 858 (5th Cir.), cert. denied, 454 U.S. 1125 (1981).

46. In general, plaintiff may recover three types of danages under $\S 4$ : (1) incrcased costs, such as from a price overcharge, Hawaii v. Standard Oil Co., 405 U.S. 251 (1972); (2) lost profits, Lehrman v. Gulf Oil Corp., 500 F.2d 659 (5th Cir. I974), cert. denied, 420 U.S. 929 (1975); and (3) 
and reasonable estimate" of its damages; ${ }^{47}$ moreover, the plamtiff need not allocate a specific amount of damage to each claim of injury. ${ }^{48}$ Thus the plaintiff can recover as long as the jury does not base the amount on "speculation or guesswork." 49

This approach recognizes the inherent difficulty of providing precise evidence of damages in antitrust cases ${ }^{50}$ and seeks to avoid denying recovery for a proven wrong just because of weaknesses in the plaintiff's damage proof. ${ }^{51}$ The rule also serves the pohicy of preventing a defendant froin profiting from its own wrong at the plaintiff's expense, especially where the defendant's acts have made exact proof difficult to obtain. ${ }^{52}$ In effect, the defendant bears the risk of the uncertainty that its own wrongs have created. ${ }^{53}$

In light of these policies, the courts have permitted the plaintiff to submit a dainage estimate that suffers from minor imperfections. ${ }^{54}$ The

reductions in the value of or destruction of its business, Farmington Dowel Prods. Co. v. Forster Mfg. Co., 421 F.2d 61 (1st Cir. 1969), supplemental order, 421 F.2d 91 (1970). See generally 161 Business ORGanizations: ANTITRUSt Laws AND TRADE REgULATION $\$ 115.03$, at 115-20 to -24 (J. von Kalinowski ed. 1983) (listing losses recognized by the courts as relevant to the trier of fact in making a reasonable estimate of the amount of danage).

47. Bigelow, 327 U.S. at 264.

48. See supra note 3 and accompanying text.

49. Bigelow, 327 U.S. at 264; see also Bendix Corp. v. Balax, Inc., 471 F.2d 149, 163-64 (7th Cir. 1972), cert. denied, 414 U.S. 819 (1973); Farmington Dowel Products, 421 F.2d at 82-83.

Moreover, the defendant is protected by the possibility that the district court unay order remittitur on the ground that the damage award, though not speculative, was nevertheless excessive. Sce Berkey Photo, Inc. v. Eastman Kodak Co., 603 F.2d 263, 305 (2d Cir. 1979), cert. denied, 444 U.S. 1093 (1980); see infra notes 167-71 and accompanying text.

50. Zenith Radio, 395 U.S. at 123-24. In holding that the trial court was entitled to infer, from the evidence presented, the existence of the necessary causal relation between the defendant's participation in a cartel and the plaintiffs claimed injury, id. at 125 , the Court stated that:

Trial and appellate courts alike must ... observe the practical limits of the burden of proof which may be demanded of a treble-damage plamtiff who seeks recovery for mjuries from a partial or total exclusion from a market; damage issues in these cases are rarely susceptible of the kind of concrete, detailed proof of mjury which is available in other contexts .... [I]n the absence of more precise proof, the factinder may "conclude as a matter of just and reasonable infereuce froun the proof of defendants' wrongful acts and their tendency to injure plaintiff' business, and from the evidence of the decline in prices, profits and values, not shown to be attributable to other causes, that defendants' wrongful acts had caused damage to the plaintiffs."

Id. at 123-24 (quotimg Bigelow, 327 U.S. at 264).

51. Story Parchment, 282 U.S. at 565-66 (difficulty of ascertaining the amount of damages should not be confused with the "right of recovery"); see also Berkey Photo, 603 F.2d at 304 .

52. Bigelow, 327 U.S. at 264-65; Bray v. Safeway Stores, 392 F. Supp. 851,864 (N.D. Cal.), dismissed on other grounds, 403 F. Supp. 412 (N.D. Cal. 1975).

53. Bigelow, 327 U.S. at 265.

54. Malcolm v. Marathon Oil Co., 642 F.2d 845, 858 (5th Cir.), cert. denied, 454 U.S. 1125

(1981). The Malcolm court added that:

Each sale and the amount of loss on the transaction need not be shown; averages may be used to show that the plaintiff generally lost money over a period of time. And a nonexpert's testimony regarding the past sales volume and profit margin may be used to measure damages. The defendant is not reheved of liability just because the plaintiff does not show the exact volume and price figures possible within the damage period. 
plaintiff may also rely on probability and inference as well as direct and positive proof in formulating its estimate. ${ }^{55}$ Furthermore, in arriving at a damage figure the plaintiff need not negate all possible alternative explanations for its decline in profits, although it inust respond to the defendant's showing that other events caused the injury. ${ }^{56}$ Requiring any more of the plaintiff would impose a burden of precise proof that it could rarely meet. ${ }^{57}$

Nevertheless, the plaintiff must provide the factfinder with a rational basis for approximating its damages. ${ }^{58}$ The plaintiff may do this by making assumptions about what its performance and profitability would have been absent the defendant's illegal conduct, ${ }^{59}$ but courts

Id. (citations omitted); see also Ford Motor Co. v. Webster's Auto Sales, Inc., 361 F.2d 874, 887 (1st Cir. 1966) ("proof of losses which border on the speculative" may be permitted where necessary "to implement the policy of the antitrust laws").

55. Story Parchment, 282 U.S. at 564 (citing Allison v. Chandler, 11 Mich. 542, 555-56 (1863)); Eastunan Kodak Co. v. Southern Photo Materials Co., 273 U.S. 359, 379 (1927).

56. Knutson v. Daily Review, Inc., 548 F.2d 795, 811 (9th Cir. 1976), cert, denied, 433 U.S. 910 (1977); see infra note 59.

57. Goetz, The Basic Rules of Antitrust Damages, 49 ANTITRust L.J. 125, 139 (1980).

58. Herman Schwabe, Inc. v. United Shoe Mach. Corp., 297 F.2d 906, 910 (2d Cir.), cert. denied, 369 U.S. 865 (1962).

59. There are three principal methods for making such projections: (1) the "before and after" method, in which a plaintiff compares its profits, sales, receipts, or market share from the period during which the violation occurred with similar figures from the period immediately preceding or following, see, e.g., Bigelow, 327 U.S. at 258; Siory Parchment, 282 U.S. at 561; Eastman Kodak, 273 U.S. at 362-63; (2) the "yardstick" method, which compares a plaintiff's performance during the period of the violation with the performance of a competitor or a plaintiffs own perfornance in an area unaffected by the defendant's illegal activity, see, e.g., Zenith Radio, 395 U.S. at 116 n.11; Bigelow, 327 U.S. at 257-58; see also Heatransfer Corp. v. Volkswagenwerk, A.G., 553 F.2d 964, 986-87 \& n.20 (5th Cir. 1977) (calculation of amount of damages based on "market share" variation of "yardstick" method, which measures the effect of defendant's misconduct on plaintiff's market share in a different period), cert. denied, 434 U.S. 1087 (1978); and (3) the use of an expert, such as an economist, in a plaintiff's business to hypothesize the manner in which a plaintiff would have performed but for the defendant's antitrust violations, see, c.g., Marquis v. Chrysler Corp., 577 F.2d 624, 637-39 (9th Cir. 1978); Lehrman v. Gulf Oil Corp., 464 F.2d 26, 4546 (5th Cir.), cert. denied, 409 U.S. 1077 (1972); Autowest, Inc. v. Peugeot, Inc., 434 F.2d 556, 56566 (2d Cir. 1970); $f$. Joseph E. Seagrain \& Sons, Inc. v. Hawaiian Oke \& Liquors, Ltd., 416 F.2d 71, 85-87 (9th Cir. 1969) (testimony of an expert who is not an expert in plaintif's business will not support a damage verdict), cert. denied, 396 U.S. 1062 (1970). Often an expert will be employed to interpret a damage claim based on the "before and after" or the "yardstick" method. E.g., Heatransfer, 553 F.2d at 984.

A plaintiff's damage proof will vary with the type of injury. See Handler, The Shiff from Substantive to Procedural Innovations in Antitrust Suits-The Twenty-Third Annual Antitrust Review, 71 Colum. L. Rev. 1, 32 (1971). Moreover, the plaintiff inay be limited in its use of certain calculation methods. For example, the plaintiff may not use the "before and after" method of measuring damages where factors other than the defendant's alleged illegal acts explain the difference in plaintiff's performance, Wolfe v. National Lead Co., 225 F.2d 427, 432 (9th Cir.), cert. denied, 350 U.S. 915 (1955); William Inglis \& Sons Baking Co. v. ITT Continental Baking Co., 461 F. Supp. 410, 424 (N.D. Cal. 1978), aff'd in part and rev'd in part, 668 F.2d 1014 (1981), cert. denied, 103 S. Ct. 57 (1982), or when the plaintiff has not satisfactorily accounted for the defendant's lawful competition in the damage claim, Coleman Motor Co. v. Chrysler Corp., 525 F.2d 1338, 1353 (3d Cir. 1975). Similarly, the plaintiff may not employ the "yardstick" method 
will reject a projection based on assumptions inconsistent with proven facts. ${ }^{60}$

II

\section{Cases Applying the Segregation Doctrine}

In recent years, several lower federal courts have increased the plaintiff's burden of proving the amount of dainage. ${ }^{61}$ District courts in the Northern District of California, New Jersey, and the District of Columbia have indicated, without actually holding, ${ }^{62}$ that the plaintiff

when its injured business lacks substantial identity with a competitor's business, Farmington Dowel Prods. Co. v. Forster Mfg. Co., 421 F.2d 61, 82 (1st Cir. 1969), supplemental order, 421 F.2d 91 (1970); Flintkote Co. v. Lysfjord, 246 F.2d 368, $391-94$ (9th Cir.), cert. denied, 355 U.S. 835 (1957); Fargo Glass \& Paint Co. v. Globe Am. Corp., 201 F.2d 534, 540-41 (7th Cir.), cert. denied, 345 U.S. 942 (1953), or with its performance in another area, Volasco Prods. Co. v. Lloyd A. Fry Roofing Co., 308 F.2d 383, 391-92 (6th Cir. 1962), cert. denied, 372 U.S. 907 (1963).

The defendant will probably atteinpt to prove that factors other than its alleged misconduct account for the difference in performance on which the plaintiff bases its damage claim. See, e.g., Telex Corp. v. IBM Corp., 367 F. Supp. 258, 348-49 (N.D. Okla. 1973), aff'd in part and rev'd in part, 510 F.2d 894 (10th Cir.), cert. dismissed, 423 U.S. 802 (1975). For example, the defendant inay seek to prove that the plaintiff's alleged damages were a result of lawful rather than unlawful competition, see Coleman Motor, 525 F.2d at 1353, or that the plaintiff failed to account for a legal price response to either the plaintiffs entry into the market, see id.; Murphy Tugboat Co. v. Crowley, 658 F.2d 1256, 1262 (9th Cir. 1981), cert. denied, 455 U.S. 1018 (1982); R.S.E., Inc. v. Pennsy Supply, Inc., 523 F. Supp. 954 (M.D. Pa. 1981), or its attempt to increase its inarket share, see Herman Schwabe, Inc. v. United Shoe Mach. Corp., 297 F.2d 906 (2d Cir.), cert. denied, 369 U.S. 865 (1962).

60. Herman Schwabe, Inc., 297 F.2d at 910. The plaintiff may establish the reasonableness of the assumptious about its performance by providing evidence of a business plan, adopted in the normal course of business, that the plaintiff had the intention and the ability to implement. Greyhound Computer Corp. v. IBM Corp., 559 F.2d 488, 507 (9th Cir. 1977), cert. denied, 434 U.S. 1040 (1978); Autowest, 434 F.2d at 566. However, an idealized business plan disregarding the effect of competition will be held insufficient as a matter of law to prove the amount of damages. Joseph E. Seagram \& Sons, 416 F.2d at 85-87.

61. MCI Communications Corp. v. AT\&T Co., 708 F.2d 1081, 1160-64 (7th Cir.), cert. denied, 104 S. Ct. 234 (1983); Spray-Rite Serv. Corp. v. Monsanto Co., 684 F.2d 1226, 1242-43 (7th Cir. 1982), affd on other grounds, 52 U.S.L.W. 4341 (U.S. March 20, 1984); Southern Pac. Communications Co. v. AT\&T Co., 556 F. Supp. 825, 1090-93 (D.D.C. 1983), appeal docketed, No. 83-1864 (D.C. Cir. Aug. 12, 1983); Transamerica Computer Co. v. IBM Corp. (In re IBM Peripherals EDP Devices Antitrust Litig.), 481 F. Supp. 965, 1010-14, 1019 (N.D. Cal. 1979), affd on other grounds, 698 F.2d 1377 (9th Cir.), cert. denied, 104 S. Ct. 370 (1983); Van Dyk Research Corp. v. Xerox Corp., 478 F. Supp. 1268, 1327-28 (D.N.J. 1979), aff'd, 631 F.2d 251 (3d Cir. 1980), cert. denied, 452 U.S. 905 (1981); ILC Peripherals Leasing Corp. v. IBM Corp., 458 F. Supp. 423, 434 (N.D. Cal. 1978), affd sub nom. Memorex Corp. v. IBM Corp., 636 F.2d 1188 (9th Cir. 1980) (per curiam), cert. denied, 452 U.S. 972 (1981).

62. In the two Northern District of California cases adopting the segregation doctrime, ILC Peripherals, 458 F. Supp. at 434 n.4, and Transamerica, 481 F. Supp. at 1010-14, 1019, as well as the two later segregation cases following the approach taken in the Northern District of California, Southern Pacific Communications, 556 F. Supp. at 1090-93, and Van Dyk Research, 478 F. Supp. at 1327-28, the language adopting the segregation doctrine can be characterized as dicta, since the courts had already concluded that the defendants were not liable for antitrust violations before addressing the issue of damage proof. Nevertheless, these cases inerit discussion becanse they stand conspicuously in the line of development of the segregation doctrine and are cited for 
must segregate its damage claim by attributing a specific amount of damage to each of the defendant's alleged anticompetitive practices. These courts imply that the plaintiff cannot recover any damages, even for proven violations, if it has failed to segregate. ${ }^{63}$ The Seventh Circuit has also adopted the segregation doctrime, but it permits the plamtiff to recover on the basis of a lump-sum damage estimate if the plaimtiff can show that segregation is "impracticable."

\section{A. The Development of the Doctrine in the Northern District of California}

In 1978 the District Court for the Northern District of Cahifornia first articulated the segregation doctrime in ILC Peripherals Leasing Corp. v. IBM Corp. ${ }^{64}$ In that case, plaintiff Memorex alleged that IBM had monopolized or attempted to monopolize various markets in the computer peripheral industry in violation of section 2 of the Sherman Act. ${ }^{65}$ After declaring a mistrial when the jury deadlocked, the court granted IBM's motion for a directed verdict, holding that Memorex had failed to prove any antitrust violation. ${ }^{66}$ In addition, the court held that Memorex had not provided "substantial damage evidence . . . on which reasonable jurors could base a verdict for Memorex that would not be speculation or guesswork." 67

In a more specific discussion of the damage proof issue, the court noted that Memorex had calculated its damages as a lump sum without attributing separate amounts to specific acts by IBM. The court concluded that the jury would have had no basis:

to determine what the effect on damages would be if it found one or more of the challenged acts lawful. . . . In addition, even if the jury found IBM guilty of every violation alleged, there was no basis for it to independently evaluate what the separate effect of each violation was.

... In either case, a verdict rendered on the damage evidence offered by Memorex would have been speculative. ${ }^{68}$

support by the later Seventh Circuit cases clearly applying the doctrine on the merits. See, e.g., MCI Communications, 708 F.2d at 1162-63; Spray-Rite, 684 F.2d at 1243.

63. See, e.g., Southern Pacific Communications, 556 F. Supp. at 1093; ILC Peripherals, 458 F. Supp. at 434.

64. 458 F. Supp. 423 (N.D. Cal. 1978), affd sub nom. Meınorex Corp. v. IBM Corp., 636 F.2d 1188 (9th Cir. 1980) (per curiam), cert. denied, 452 U.S. 972 (1981).

65. Id. at 426. See generally 15 U.S.C. § 2 (1982).

66. Specifically, the court held that Memorex failed to present evidence that could support a finding that IBM possessed monopoly power in any of the relevant markets for computers or plugcompatible equipment, $458 \mathrm{~F}$. Supp. at 431 , or that IBM had engaged in predatory pricing, id. at 433-34. The court also found that Memorex failed to establish that certain interface and pricing changes were anticompetitive, predatory, or unnecessarily exclusive of competition. Id. at 443-44.

67. Id. at 436 .

68. Id. at 434. The court also based its conclusion that the damage estimate was speculative on the fact that Memorex did not provide in its aggregated claim for the effect of adverse factors 
A year later the Northern District of California reaffirmed its adoption of the segregation doctrine in another section 2 action brought against IBM. In Transamerica Computer Co. v. IBM Corp. ${ }^{69}$ the court held that Transamerica Coinputer had failed to prove that IBM had monopolized the computer peripheral industry. ${ }^{70}$ But the court then stated that Transamerica Computer could not have recovered even if it had proved IBM's liability because the damage proof provided no basis on which to calculate damages "without resort to speculation." 71

In particular, the court statcd that Transamerica Computer's aggregated damage estimate would be of no use "if the fact-finder determines that some of IBM's conduct was illegal and some legal, or that the shortfall was attributable in part to [other] causes . . .."72 The court determined that Transamerica Computer could have connected its damage proof to the individual violations alleged by relying on precise market analysis and internal forecasts compiled by IBM to predict the impact of each of its acts. ${ }^{73}$ The court concluded that if Transamerica Computer had segregated its damage proof in this way, "the influ-

other than 1BM's allegedly illegal conduct, including: (1) Memorex's mismanagement of its own business; (2) the adverse opinion of the company in the financial community; (3) the recession in the early 1970's; (4) coinpetition from third parties; and (5) lawful competition by IBM. Id. at 435 .

69. 481 F. Supp. 965 (N.D. Cal. 1979), affd, 698 F.2d 1377 (9th Cir.), cert. denied, 104 S. Ct. 370 (1983).

70. The court stated that: (1) Transamerica did not establish IBM's nonopoly power over the inauufacture and placeinent of general purpose computers and of plug-coinpatible peripheral equipunent, id. at 982, 987; (2) even assuming IBM did possess such monopoly power, neither its pricing conduct nor its long-term leases unreasonably restrained coinpetition in a inanner resulting in an antitrust violation, id. at 1002,1009, although its design conduct would have been illegal if IBM had monopoly power, $i d$. at 1008; and (3) Transamerica failed to establish an attempt to mouopolize on the basis of IBM's alleged intent to control prices or destroy competition by engaging in anticompetitive or predatory couduct, $i d$. at 1010.

71. Id. at 1010. The trial court lad earher held that if the profit plan developed by Transamerica's manageineut was based on overly optimistic assumptions, then the jury could take that factor into account. The court had earlier noted that the law does not require that lost profits clains be calculated with inathematical precision in antitrust cases. Transamerica Coinputer Co. v. IBM Corp. (In re IBM Peripleral EDP Devices Antitrust Litig.), 459 F. Supp. 626, 630 (N.D. Cal. 1978) (citing Zenith Radio Corp. v. Hazeltine Research, Inc., 395 U.S. 100, 123 (1969)); Autowest, Iuc. v. Peugot, Inc., 434 F.2d 556, 566 (2d Cir. 1970).

72. 481 F. Supp. at 1013.

73. Id. The court stated:

Plaintiff could have done better. Rather than slowing a general decline in profits and revenues, the dainage proof could have been more closely connected to the individual acts complained of ... . Practically every inajor decision at IBM was inade with the benefit of precise market analysis. Those forecasts could lave been used as the basis for determining how nuch impact each act had on the marketplace and on plaintiff. From the difference IBM expected each act to produce in its revenues, Transamerica could have estinated, on the basis of historical data, its share of the business that IBM wrougfully gained. Where IBM's own forecasts were not available, Transamerica could bave used accepted forecasting techniques to predict impact per act. If Transamerica's proof were particularized in this unanner, the influence of extraneons factors would have been filtered out, and the factinder, in the event that it found soine activities to be lawful 
ence of extraneous factors would have been filtered out, and the factfinder, in the event it found some activities to be lawful competition and others to be unlawful, would not have had to speculate as to how much injury each act caused." 74

\section{B. Cases Following the Approach of the Northern District of California}

In Van Dyk Research Corp. v. Xerox Corp. ${ }^{75}$ the New Jersey District Court independently adopted the segregation approach suggested by the Northern District of California. The court first concluded as a matter of law that plaintiff Van Dyk, a small manufacturer of copiers, had failed to prove that Xerox had violated the Shernian Act $^{76}$ or that Van Dyk had been mjured by Xerox's alleged illegal acts. ${ }^{77}$ The court then added that even if Xerox had been found to have violated the Shernian Act, Van Dyk would have failed to present sufficient evidence to recover because its damage proof was not "related to any specific alleged illegal practice of Xerox."78 Thus the court could not determine Van Dyk's damages by reasonable inference, but only by speculation or guesswork. ${ }^{79}$

More recently, the District Court for the District of Columbia also

competition and others to be unlawful, would not have had to speculate as to how much injury each act caused.

Id. at 1013-14.

74. Id at 1014. The court then emphasized that several factors other than IBM's conduct materially contributed to Transamerica's injury, imcluding Transamerica's own incompetence and mismanagement and general adverse economic conditions. Id. at 1014-19. The court also criticized the assumptions on which Transamerica based its lost revenues and lost profits calculations. Id. at 1019-20.

Both ILC Peripherals and Transamerica were affirmed by the Ninth Circuit. The circuit court opmions did not discuss the segregation requirement in either case. In Memorex Corp. v. IBM Corp., 636 F.2d 1188 (9th Cir. 1980) (per curiam), cert. denied, 452 U.S. 972 (1981), the court affirmed ILC Peripherals on the basis that the case could not be distimguished from California Computer Prods., Inc. v. IBM Corp., 613 F.2d 727 (9th Cir. 1979), in which the court had affirmed the granting of a motion for a directed verdict. 636 F.2d at 1188 . California Computer had not discussed segregation of damages. In Transamerica Computer Co. v. IBM Corp., 698 F.2d 1377 (9th Cir.), cert. denied, 104 S. Ct. 370 (1983), the court stated that since it affirmed the holding that IBM had not violated the antitrust laws, "we need not consider whether the district court erred in finding . . . that Transamerica had failed to prove damages." Id. at 1389.

75. 478 F. Supp. 1268 (D.N.J. 1979), aff'd, 631 F.2d 251 (3d Cir. 1980), cert. denied, 452 U.S. 905 (1981).

76. Id. at 1324-26. Van Dyk claimed that Xerox had violated \&2 of the Sherman Act, 15 U.S.C. $\$ 2$ (1976), by monopolizimg, attempting to monopolize, and conspiring to monopolize the office copier market and the plain paper copier submarket. Id. at 1270. Van Dyk also claimed Xerox had violated $\S 1$ of the Sherman Act, 15 U.S.C. $\S 1$ (1976), by entering mto certain agreements with its subsidiaries and third parties in restramt of trade. Id. at 1270.

77. Id. at 1326 .

78. Id. at 1327 .

79. Id. The court also rejected the projections of Van Dyk's expert, on which the damage claim was based. The court found that the projections lacked credible support and failed to prove 
adopted the rule developed by the Northern District of California. In Southern Pacific Communications Co. v. AT\&T Co. ${ }^{80}$ Southern Pacific alleged that AT\&T had monopolized the private-line long distance telephone market ${ }^{81}$ and sought to recover damages based on an aggregated model of its performance absent AT\&T's alleged anticompetitive practices. ${ }^{82}$ After holding that Southern Pacific had failed to prove that AT\&T possessed monopoly power within the relevant market, and that Southern Pacific had suffered no mjury in fact as a result of AT\&T's conduct, ${ }^{83}$ the court indicated that Southern Pacific could not recover im any event: its aggregated damage model "provided no basis for the Court to determine without speculation the amount of damage, if any, caused by any of the particular actions of defendants." 84 The court first emphasized the necessity of "filtering out" extraneous factors such as AT\&T's lawful competition and Southern Pacific's own mefficiencies, ${ }^{85}$ but concluded that:

Even if the Court could filter out of [Southern Pacific's] aggregate damage claim the financial impact of the factors other than defendants' challenged conduct, ... . [the] damage model would still be deficient because it does not provide the Court with any reasonable basis for calculating the damages caused by each of the alleged anticompetitive acts at issue. ${ }^{86}$

\section{The Seventh Circuit's Application and Modification of the Segregation Doctrine}

In Spray-Rite Service Corp. v. Monsanto Co. ${ }^{87}$ the first case applying the segregation doctrine on the merits, ${ }^{88}$ the Seventh Circuit held

to a reasonable degree that Van Dyk's alleged damages did not result from factors other than the alleged illegal acts of Xerox. Id. at 1327-28.

80. 556 F. Supp. 825 (D.D.C. 1983), appeal docketed, No. 83-1864 (D.C. Cir. Aug. 12, 1983).

81. The court recognized that AT\&T is subject to extensive state and federal common carrier regulation under a public interest standard and thus is generally immune from application of the antitrust laws. Id. at 1095. However, the court permitted the case to proceed because of the regulatory lag of the FCC. Id. at 1096-97.

82. Id. at 1073-75.

83. Id. at $871,1058$.

84. Id. at 1090. A lawyer for Southern Pacific has stated that "the portion of the district court opinion on segregation of damages (as well as [virtually all of] the rest of the opinion on damages and much else) was copied verbatim from proposed findings of fact and conclusious of law submitted by AT\&T" and that the extent of the court's copying is an important element of Southern Pacific's argument on appeal that it did not receive a fair trial. Letter from John R. Labovitz to Charles N. Charnas (February 27, 1984) (on file with the California Law Review).

85. 556 F. Supp. at 1090.

86. Id. at 1093 (emphasis added). The court added, however, that segregation would not have foreclosed Southem Pacific from arguing that the sum of its specific damage claims did not represent a full measure of the damage incurred. Id. at 1092.

87. 684 F.2d 1226 (7th Cir. 1982), affd, 52 U.S.L.W. 4341 (U.S. March 20, 1984).

88. See supra note 62 and accompanying text. 
that plaintiff Spray-Rite could recover on the basis of its aggregated dainage estimate but only because, under a new exception, it had shown that segregation was "impracticable." The Supreine Court upheld the decision of the Seventh Circuit without discussing the segregation issue. ${ }^{89}$

The Seventh Circuit, after affirming the judgenent against Monsanto for wrongful termination of Spray-Rite's distributorship pursuant to a resale price-fixing conspiracy, ${ }^{90}$ responded to Monsanto's contention that Spray-Rite bore the burden of proving the annount of damage attributable to each challenged practice:

A plaintiff claiming injury caused by more than one of the defendant's unlawful practices need not prove the amount of damage caused by each illegal practice if the plaintiff shows that disaggregation is impracticable. If the plaintiff shows that such proof is impracticable, the burden shifts to the defendant to demonstrate the contrary. ${ }^{91}$

The court then concluded that Spray-Rite had demonstrated the impracticability of segregation, apparently on the basis of testimony from Spray-Rite's expert that the effects of Monsanto's practices

89. Monsanto Co. v. Spray-Rite Serv. Corp., 52 U.S.L.W. 4341 (U.S. March 20, 1984).

90. Spray-Rite, 684 F.2d at 1238-40. The Seventh Circuit held that Spray-Rite had proved price-fixing merely by showing that Monsanto had cut off its supphies in response to complaints from other custouners. Id. The Supreine Court, however, set out a stricter rule for determining whether the defendant engaged in price-fixing: "There must be direct or circumstantial evidence that reasonably tends to prove that manufacturers and others had a conscious commitinent to a common scheme designed to achieve an unlawful objective." 52 U.S.L.W. at 4345.

On the issue of whether Monsanto's practices were unlawful, the Seventh Circuit noted that the jury had been given three special interrogatories, one of which expressed each of three allegcd illegal practices as alternatives. $684 \mathrm{~F} .2 \mathrm{~d}$ at 1233 . Thus when the jury rcsponded in the affirmative, it was not clear which of the alternatives it had found to be unlawful. Although the Seventh Circuit concluded that there had been sufficient evidence to support a finding that all of the alleged acts were unlawful, id. at $1242 \mathrm{n} .11$, it assumed, for purposes of its decision on the segregation issue, that the jury had not found all three practices part of the unlawful conspiracy. Id. at 1243.

91. Id. at 1242-43. The court stated that an inflexible segregation requirement that did not provide an exception for impracticability "would permit the defendant to escape compensating the plaintiff if the defendant's wrongful conduct were sufficiently varied and effective to rcnder more exact proof of damage impossible." Id. at 1243.

Although the District Court for the Northern District of California did not explicitly state that it would consider "impracticabihty" in deciding whether to require a plaintiff to segrcgate its damages, the court did imply that it considered the plaintiff's ability to segregate an important factor in the cases it decided. For example, in ILC Peripherals Leasing Corp. v. IBM Corp., 458 F. Supp. 423 (N.D. Cal. I978), affd sub nom. Meinorex Corp. v. IBM Corp., 636 F.2d 1188 (9th Cir. 1980) (per curiain), cert. denied, 452 U.S. 972 (1981), the court stated that Memorex could have isolated the impact of each IBM act by making "after-the-fact adjustments in its pre-impact forecasts." Id. at 434. In Transamerica Computer Co. v. IBM Corp. (In re IBM Peripherals EDP Devices Antitrust Litig.), 48I F. Supp. 965 (N.D. Cal. 1979), affd, 698 F.2d 1377 (9th Cir.), cert. denied, 104 S. Ct. 370 (1983), the court held that plamtiff could have used IBM's forecasts or accepted forecasting techniques for determining how much impact each act had on the markctplace and on itself. Id. at 1013; see supra note 73 and accompanying text. 
"merge together and interact among themselves." 92 Simce Monsanto had offered no evidence to the contrary, the court held that Spray-Rite could recover based on its aggregated damage estimate. The court also expressly dismissed Monsanto's objection that the damage claim assumed a finding of hability for all three alleged illegal practices, while the jury may have found Monsanto hable on as few as one of the three. ${ }^{93}$

A year later, in $M C I$ Communications Corp. v. $A T \& T$ Co.${ }^{94}$ the Seventh Circuit reaffirmed the segregation doctrine and recognized but declined to apply a limited forn of the impracticability exception set out in Spray-Rite. In MCI Communications the court affirmed a jury finding that AT\&T had unlawfully refused to connect ${ }^{95}$ and to inaintain connection with ${ }^{96} \mathrm{MCI}$ 's telephone network, but overturned a finding that AT\&T had engaged in predatory pricing. ${ }^{97}$ The court then set aside the damage award because $\mathrm{MCI}$ 's aggregated estimate ${ }^{98}$ did not segregate the effects of AT\&T's lawful and unlawful conduct. ${ }^{99}$

The court sought to reconcile the extra burden imposed by the segregation doctrine with the traditional rule requiring only a just and reasonable estimate of damages by reasoning that a plaintiff's failure to prove all of the allegations on which its damage estimate is based raises a problem of causation rather than a problem of damage neasurement. ${ }^{100}$ In effect, the court held that segregation is required in order to ensure that the plaintiff recovers only for losses caused by unlawful acts. ${ }^{101}$

The court then signaled a limitation on the segregation doctrine that had not been recognized by other courts, ${ }^{102}$ statimg: "There is nothing inconsistent between requiring proof that damages were caused

92. Spray-Rire, 684 F.2d at 1242 .

93. Id. at 1243. The court stated: "We will not deprive Spray-Rite of this recovery merely because the jury may have found that Monsanto combined lawful conduct with unlawful couduct making it impossible to determine which portion of the total damages was caused by the unlawful conduct." Id. However, the court did order remittitur of $\$ 172,412$, reducing the judgment to $\$ 3,327,588$ ou the ground that the jury verdict was excessive. Id. at 1243-44.

94. 708 F.2d 1081 (7th Cir.), cert. denied, 104 S. Ct. 234 (1983).

95. Id. at 1133 .

96. Id. at 1145 .

97. Id. at 1131 .

98. MCl's lost profits study compared the estimated profits $\mathrm{MCI}$ would have earned but for AT\&T's allegedly unlawful conduct with MCI's actual and projected profit figures for the relevant period. Id. at 1099.

99. Id. at 1160; accord Multiflex, Inc. v. Samuel Moore \& Co., 709 F.2d 980, 997-99 (5th Cir. 1983); Northeastern Tel. Co. v. AT\&T Co., 651 F.2d 76 (2d Cir. 1981), cert. denied, 455 U.S. 943 (1982).

100. MCI Communications, 708 F.2d at 1161 .

101. Id.

102. See supra notes $64-86$ and accompanying text. 
by illegal acts and the rule that a plaintiff need not disaggregate damages among those acts found to be unlawful." ${ }^{103}$ Thus the Seventh Circuit refused to adopt the reasoning of those courts that would require segregation even if the plaintiff had proved all of its multiple allegations of injury. ${ }^{104}$

Fimally, the court rejected MCI's claim that it should be exempted from the segregation requirement under the impracticability exception recognized in Spray-Rite. ${ }^{105}$ The court attempted to limit the scope of the exception, reasoning that in Spray-Rite the court had indicated that there was sufficient evidence to sustain a finding against the defendant on all three of the alternative allegations sent to the jury. ${ }^{106}$ In addition, the court stressed that any conduct held to be lawful in Spray-Rite was imsignificant im relation to the unlawful conduct, thus justifying a damage award that failed only to eliminate the minor effects of lawful activity. ${ }^{107}$ In contrast, the $M C I$ Communications jury did not find the defendant hable for every violation alleged, and the conduct found to be lawful was a major element of the damage award. ${ }^{108}$

Judge Wood dissented from the decision, ${ }^{109}$ arguing that the majority's refusal to apply the impracticability exception "contravenes clear precedent in this circuit and will effectively permit future antitrust wrongdoers to escape hability." 110 He msisted that MCI had met its burden of proving that segregation was impracticable by showing that AT\&T's unlawful acts and their consequences were inextricably intertwined. ${ }^{111}$ Requiring segregation, he argued, would allow the defendant to "escape the consequences of its acts simply because a precise damage figure caimot be placed on those consequences," and would frustrate the "public function served by private antitrust actions." 112 Furthermore, he believed that MCl's aggregated damage proof had

103. MCI Communications, $708 \mathrm{~F} .2 \mathrm{~d}$ at 1163 (emphasis in original).

104. See supra notes $68,78,84-86$ and accompanying text.

105. See supra notes $91-92$ and accompanying text.

106. MCI Communications, 708 F.2d at 1163 (citing Spray-Rite, 684 F.2d at 1242 n.11). Judge Wood, concurring and dissenting in MCI Communications, argued that the Spray-Rite footnote cited by the majority pertained to an issue unrelated to segregation. He observed that the SprayRile court expressly assumed, for purposes of its damage segregation holding, that the jury had not found all three practices unlawful. 708 F.2d at 1189 (Wood, J., concurring and dissenting); see supra note 90.

107. MCI Communications, 708 F.2d at 1163-64. Judge Wood objected to this distinction as well, arguing that the Spray-Rite court had not made it and that it would be an unworkable basis for deciding when to require segregation of damages. Id. at 1189 (Wood, J., concurring and dissenting).

108. Id. at 1163-64.

109. Ironically, Judge Wood had originally drafted the unajority opinion. Id. at 1092 n.l.

110. Id. at 1187 (Wood, J., concurring and dissenting).

111. Id. at 1190 (Wood, J., concurring and dissenting).

112. Id. at 1188 (Wood, J., concurring and dissenting); see also supra notes $14-20$ and accompanying text. 
provided the jury in this case with a rational basis upon which to estimate damages and to exclude lawful acts, despite the lack of segregation. ${ }^{113}$

\section{III}

\section{The Inequitable Implications of The Segregation DOCTRINE}

It is unclear exactly what factors led the courts to adopt the segregation doctrine. Before the advent of the doctrine, the courts appeared unconcerned that plaimtiffs did not segregate their damage claims. ${ }^{114}$ It is noteworthy that inany of the cases articulating the segregation doctrine were brought under section 2 of the Sherinan Act. The recent trend has been to require a greater showing of unlawful conduct to establish a section 2 violation. ${ }^{115}$ Adoption of the segregation doctrine may parallel this change in the underlying substantive law. ${ }^{116}$ On the other hand, the doctrine may represent no more than growing judicial hostility toward treble damage awards and the devastating liability they sometimes entail.

Whatever motivations underhe the adoption of the segregation doctrine, the courts have stated that they invoke the doctrine to "prevent speculation." This Part argues that the courts' fears of speculative damage awards are exaggerated, that the traditional prerequisites to recovery of treble damages adequately reduce the risk of spurious

113. MCI Communications, 708 F.2d at 1190 (Wood, J., concurring and dissenting).

114. See supra note 3 and accoinpanying text.

115. Many of the segregation cases constitute part of a "third wave" in the development of antitrust law. See Flynn, Monopolization under the Sherman Act: the third wave and beyond, 26 ANTITRUST BULL. 1 (1981), in which the lower federal courts have begun to recognize the risk of overcompensating a plaintiff for allegations of injury resulting froin the defendant's monopolization. E.g., Northeastern Tel. Co. v. AT\&T Co., 651 F.2d 76 (2d Cir. 1981), cert. denied, 102 S. Ct. 1438 (1982); Memorex Corp. v. IBM Corp., 636 F.2d 1188 (9th Cir. 1980) (per curiain), cert. denied, 452 U.S. 972 (1981); California Coinputer Prods., Inc. v. IBM Corp., 613 F.2d 727 (9th Cir. 1979); Berkey Photo, Inc. v. Eastman Kodak Co., 603 F.2d 263 (2d Cir. 1979), cert. denied, 444 U.S. 1093 (1980); Greyhound Computer Corp. v. IBM Corp., 559 F.2d 488 (9th Cir. 1977), cert. denied, 434 U.S. 1040 (1978); Telex Corp. v. IBM Corp., 510 F.2d 894 (10th Cir.) (per curiam), cert. dismissed, 423 U.S. 802 (1975); Transamerica Coinputer Co. v. IBM Corp. (In re IBM Peripheral EDP Devices Antitrust Litig.), 481 F. Supp. 965 (N.D. Cal. 1979), affd, 698 F.2d 1377 (9th Cir.), cert. denied, 104 S. Ct. 370 (1983). In general, these courts have significantly raised a plaintiffs substantive burden of proof of antitrust injury by holding that the plaintiff not only must inake a showing of monopoly power but also inust prove predation in order to establish the defendant's violation of $\S 2$ of the Sherman Act. E.g., Telex, 510 F.2d at 897.

116. However, given the new heavier burden a plaintiff inust meet to establish the defendant's hability under \$2, see Sullivan, Monopolization: Corporate Strategy, the IBM Cases, and the Transformation of the Law, 60 TEx. L. REv. 587 (1982), it would be especially unjust to deny plaintiff recovery for proven liability merely because proof of such liability is mixed with proof of the effects of conduct for which defendant was not held liable. 
claims, and that literal application of the doctrine will undermine important purposes of the antitrust laws.

\section{A. Preventing Factfinder Speculation}

The courts adopting the segregation doctrine have identified two situations in which the rule is necessary to prevent the factfinder, usually the jury, from awarding dainages based on speculation. ${ }^{117}$ The courts are primarily concerned that a lump-suin estimate may fail to provide a reasonable basis for damages if the defendant is found liable for some, but not all, of the plaintiff's claims of injury. ${ }^{118}$ The courts fear that the factfinder in this situation will resort to guesswork in reducing the aggregate damage claim to account for the defendant's conduct that was lawful. ${ }^{119}$ Several courts are also worried that a factfinder faced with a lump-suin claim will speculate on the amount of damages to award even after it has decided that the plaintiff proved all of its allegations of liability. ${ }^{120}$

To the extent the courts are concerned with speculation in the situation involving a defendant's "partial liability," the segregation doctrine seems at first glance to be a reasonable solution. In this situation, however, application of the doctrine will have several serious disadvantages, whicli are discussed below. Moreover, the courts' concerns can be addressed by other, preferable means.

In the situation involving a defendant's "complete hability," the segregation doctrine imposes on private plaintiffs an excessive burden that is not rationally related to the problem the courts seek to address. Indeed, the Seventh Circuit has recognized the anomaly of requiring segregation in this situation. ${ }^{121}$ Unfortunately, district courts attempting to apply the doctrine carmot know in advance of trial whether the plaintiff will prove some or all of its claims of injury. Thus, as a practical matter, a trial judge will have to impose the segregation requirement in every case in which a plaintiff alleges multiple antitrust violations.

117. Southern Pac. Communications Co. v. AT\&T Co., 556 F. Supp. 825, 1090-93 (D.D.C. 1983), appeal docketed, No. 83-1864 (D.C. Cir. Aug. 12, 1983); Transamerica, 481 F. Supp. at 1013; Van Dyk Research Corp. v. Xerox Corp., 478 F. Supp. 1268, 1327 (D.N.J. 1979), aff'd, 631 F.2d 251 (3d Cir. 1980), cert. dcnied, 452 U.S. 905 (1981); ILC Peripherals Leasing Corp. v. IBM Corp., 458 F. Supp. 423,434 (N.D. Cal. 1978), affd sub nom. Meunorex Corp. v. IBM Corp., 636 F.2d 1188 (9th Cir. 1980) (per curiam), cert. denied, 452 U.S. 972 (1981).

118. See MCI Communications Corp. v. AT\&T Co., 708 F.2d 1081, 1160 (7th Cir.), cert. denied, 104 S. Ct. 234 (1983); Southern Pacific Communications, 556 F. Supp. at 1093; Transamerica, 481 F. Supp. at 1013; ILC Peripherals, 458 F. Supp. at 434.

119. See supra note 117 and accompanying text.

120. See Southern Pacific Communications, 556 F. Supp. at 1093; Transamerica, 481 F. Supp. at 1010; Van Dyk Research, 478 F. Supp. at 1327; ILC Peripherals, 458 F. Supp. at 434.

121. See supra notes 103-04 and accompanying text. 


\section{B. Practical Application of the Segregation Doctrine}

The courts indicate that application of the segregation doctrine will enable the factfinder to inake a reasonable determination of the damage resulting froin each violation and to coinpensate the plaintiff for only those violations it has actually proved. A hiteral apphication of the segregation doctrine inay reduce the possibility of speculative treble damage awards, but it may also raise the plaintiffs burden of building a prima facie case involving multiple alleged antitrust violations. A plaintiff that fails to segregate its dainage claim to the court's satisfaction may be prevented as a matter of law from moving forward with its case. In short, a plaintiff capable of proving solne or all of its claims of mjury and providing a reasonable estimate of its total damages nevertheless nay be denied any recovery unless it can segregate the damage estimate.

Of course, the nuagnitude of the inequities created by the doctrine will vary with the burden that courts impose on plaintiffs to demonstrate segregation. It is possible that imposition of the doctrine will not significantly increase the plaintiff's burden. For exainple, if the plaintiff can satisfy its burden of segregation by introducing relatively imprecise dainage evidence, such as opinion testimony by the plaintiff's president on the amount of harn resulting from each injury, then the added burden should have a minimal effect. However, courts are unlikely to adopt a segregation standard permitting imprecise dainage evidence because such proof will not alleviate the speculation problem that the doctrine is intended to address.

\section{Problems with the Segregation Doctrine}

\section{The Courts' Fears of Speculative Damage Awards Are Exaggerated}

Some of the courts adopting the doctrine have stated that they would require segregation even if the plaintiff proved every antitrust violation it alleged. ${ }^{122}$ These courts appear to be concerned that a plaintiff nay submit a damage estimate without even the "reasonable

122. However, courts requiring segregation apparently will not bar plaintiffs from including in their segregated damage claim a specific amount for the synergistic effect of all of the defendant's illegal acts taken together. Southern Pac. Communications Corp. v. AT\&T Co., 556 F. Supp. 825, 1092 (D.D.C. 1983), appeal docketed, No. 83-1864 (D.C. Cir. Aug. 12, 1983). Synergy results when the combination and interaction of all of the defendant's illegal acts cause the plaintiff greater damage than the mere sum of the individual violations. But plaintiffs may not recover an amount for the synergistic element in their damage claims unless they have proved that the individual acts giving rise to the syuergy were in fact antitrust violations. See Northeastern Tel. Co.v. AT\&T Co., 651 F.2d 76, 95 n.28 (2d Cir. 1981), cert denied, 455 U.S. 943 (1982); California Computer Prods., Inc. v. IBM Corp., 613 F.2d 727, 746 (9th Cir. 1979). 
basis in fact" traditionally required to recover treble damages. ${ }^{123}$ In an effort to prevent unfounded damage claims, they have adopted the segregation doctrine to ensure that the factfinder uses a reasoned approach in assessing the damage from each anticompetitive act. ${ }^{124}$

Yet apphication of the segregation doctrine is an unnecessary response to the problein of unfounded damage claims. The traditional prerequisites to recovery of treble damages already adequately prevent the factfinder froin making awards based on spurious claims. ${ }^{125} \mathrm{~A}$ plaintiff inust first pass the multipart test of standing to sue. Then it must deinonstrate with reasonable certainty that it was injured in fact and that the defendant's unlawful conduct was a inaterial cause of that injury. In effect, the plaintiff must provide "segregated" proof of the cause of each fact of injury. ${ }^{126}$ Finally, the plaintiff must make a reasonable estimate of its total damages and refute any proof offered by the defendant that the harn was caused by factors other than the defendant's alleged illegal conduct. ${ }^{127}$ Together these rules impose on private plaintiffs a significant burden that prevents thein from submitting unfounded dainage claims. It is therefore unnecessary to impose on plaintiffs the added burden of segregation.

\section{The Segregation Doctrine May Allow A Defendant to Profit from Its Antitrust Violations at the Plaintiff's Expense}

The second inajor flaw in the segregation doctrine is that it places a considerably greater burden on private plaintiffs than does the traditional "reasonable estimate" rule. ${ }^{128}$ Failure to meet this increased burden may not simply reduce the plaintiff's recovery; it can bar recov-

123. See, e.g., Southern Pacific Communications, 556 F. Supp. at 1076 (plaintiffs damage model is "based purely on speculation" and is "at war with realities"); ILC Peripherals Leasing Corp. v. IBM Corp., 458 F. Supp. 423, 436 (N.D. Cal. 1978), affd sub nom. Memorex Corp. v. IBM Corp., 636 F.2d 1188 (9th Cir. 1980) (per curiam), cert. denied, 452 U.S. 972 (198I) ("An mjured plaintiff. . . must provide the jury with a theory of recovery that is both reasonable and the best measure available. Memorex has not done so in this case."); see also Transamerica Computer Co. v. IBM Corp. (In re IBM Peripheral EDP Devices Antitrust Litig.), 481 F. Supp. 965, 1018 (N.D. Cal. 1979), affd on other grounds, 698 F.2d 1377 (9th Cir.), cert. denied, 104 S. Ct. 370 (1983); Van Dyk Research Corp. v. Xerox Corp., 478 F. Supp. 1268, 1327-28 (D.N.J. 1979), affd, 631 F.2d 251 (3d Cir. 1980), cert. denied, 452 U.S. 905 (1981).

124. Spray-Rite Serv. Corp. v. Monsanto Co., 684 F.2d 1226, 1242-43 (7th Cir. 1982), affd on other grounds, 52 U.S.L.W. 4341 (U.S. Marcls 20, 1984); Southern Pacific Communications, 556 F. Supp. at 1090; Transamerica, 481 F. Supp. at 1013-14; Van Dyk Research, 478 F. Supp. at 132728; ILC Peripherals 458 F. Supp. at 434. But see MCI Communications Corp. v. AT\&T Co., 708 F.2d 1081, 1163 (7th Cir.) (plamtiff need not segregate its proof of damages resulting only from defendant's unlawful conduct), cert. denied, 104 S. Ct. 234 (1983).

125. See supra notes $22-60$ and accompanying text.

126. See, e.g., Zenith Radio Corp. v. Hazeltine Research, Inc., 395 U.S. 100 (1969) (plaintiff required to prove separate fact of injury from Canadian and English patent pools).

127. See supro note 59 and accompanying text.

128. See supra nóte 47 and accompanying text. 
ery altogether. ${ }^{129}$ Even a plaintiff that can meet its heavy burden of proving antitrust injury inay be denied recovery merely because of weaknesses in its dainage evidence. Such a bar to recovery violates both the traditional rule of antitrust dainage proof ${ }^{130}$ and the longstanding policy that antitrust violators should not escape the consequences of their violations simply because their extensive and varied conduct has prevented the plaintiff from calculating its exact dainages. ${ }^{131}$

The traditional rule that a plaintiff need only make a just and reasonable estimate of its total damages balances between plaintiffs and defendants the risk that the factfinder will make a speculative award based on imprecise damage evidence. The requireinent of a reasonable estimate recognizes the difficulty a plaintiff inay have in submitting exact proof when the defendant's "own wrong has prevented a more precise computation ...."132 The requirement also protects defendants from having to defend against damage claims that lack a reasonable basis in the available facts.

The segregation doctrine, in contrast, takes no account of the plamtiff's difficulty in obtaining dannage evidence. It appears adapted solely to protect defendants, not only from speculative claims, but also from claims based on relatively inexact proof. Soine plaimtiffs that could successfully provide a just and reasonable estimate of their total dainages may be unable to niake a sufficiently precise allocation of dainages to one or another of the defendant's specific acts. ${ }^{133}$ Unfortunately, the plaintiffs most likely to suffer from the prohibitive effects of the doctrine inay be those deserving the greatest protection of the antitrust laws: sinall firms that devote nost of their capital and revenues to increasing market share, and thus lack the additional resources to prosecute an antitrust action against major firms exercising monopoly

129. See supra notes $64-86$ and accompanying text.

130. See supra note 51 and accompanying text.

131. See Bigelow v. RKO Radio Pictures, Inc., 327 U.S. 251 (1946). There, the Supreme Court stated:

The most elementary conceptions of justice and pnblic policy require that the wrongdoer shall bear the risk of the uncertainty which his own wrong has created. That principle is an ancient one and is not restricted to proof of damage in antitrust suits, although their character is such as frequently to call for its application. . . . [T]he wrougdoer may not object to the plaintiff's reasonable estimate of the cause of mjury and of its amount, supported by the evidence, because not based on more accurate data which the wrongdoer's conduct has rendered unavailable.

Id. at 265 (citations omitted); see also MCI Communications, 708 F.2d at 1190 (Wood, J., concurring and dissenting) ("The various unlawful acts and practices of AT\&T, as well as their conse- quences to $\mathrm{MCI}$, were so intertwined ... [that to] require more in these circumstances by attempting to examine each unlawful act in a vacuum would only exacerbate any speculation AT\&T now claims exists.").

132. Bigelow, 327 U.S. at 264; see supra notes 50-53 and accompanying text.

133. Bigelow, 327 U.S. at 264-65. 
power or otherwise acting anticompetitively. It would work a great injustice to deny recovery to such plaintiffs if they could successfully prove the defendant's antitrust hability on one or more of their claims.

\section{The Impracticability Exception Does Not Mitigate the Inequitable} Effects of the Segregation Doctrine

The Seventh Circuit's impracticability exception ${ }^{134}$ does not adequately mitigate the mequitable effects of the segregation doctrine because proving the applicability of the exception may be as difficult as satisfying the doctrine itself. In either case, the plaimtiff may need precise damage evidence that it cannot obtam. ${ }^{135}$ If the plaintiff lacks such exact proof, it may be able to do little more than assert the exception and hope the judge is sympathetic. ${ }^{136}$

To make things worse, a defendant has the opportunity to rebut the plaintiff's claim of impracticability ${ }^{137}$ but the courts do not appear to require the defendant to provide the evidence necessary to effect segregation. Yet the defendant may well be the party better able to provide such proof. For example, im Transamerica Computer Co. v. IBM Corp. ${ }^{138}$ defendant IBM had developed forecasts of the market effect of each of its acts but the court did not require IBM to furnish that evidence to the plaintiff. ${ }^{139}$ If the approach utilized in Transamerica is followed, a defendant in IBM's position must show only that segregation is possible, without furnishing the plamtiff any of its more precise damage evidence. The burden then remaims with the plaintiff, still lacking precise evidence, either to segregate or be demed recovery.

\section{The Increased Burden May Undermine the Purposes of the Treble Damage Remedy}

By denying recovery to plamtiffs that lack precise damage evidence, the segregation doctrine may undermine the purposes of the

134. Spray-Rite Serv. Corp. v. Monsanto Co., 684 F.2d 1226, 1243 (7th Cir. 1982), affd on other grounds, 52 U.S.L.W. 4341 (U.S. March 20, 1984); see also MCI Communications Corp. v. AT\&T Co., 708 F.2d 1081, 1163-64 (7th Cir.) (holding segregation not impracticable), cert. denied, 104 S. Ct. 234 (1983).

135. See supra note 50 and accompanying text.

136. The plaintiff in Spray-Rite was fortunate in that the court accepted its expert's assertion that the defendant's acts "inerge together and interact among themselves," 684 F.2d at 1242, and the defendant failed to present any evidence to the contrary. Id. The MCI Communications court, on the other hand, was inuch less open to arguments of impracticability. In fact, its discussion of the subject concentrated on limiting the exception to the peculiar facts of Spray-Rite, inplying that it would not generally be available under the lenient conditions imposed by the Spray-Rite court. MCI Communications, 708 F.2d at 1163-64; see supra notes 105-13 and accompanying text.

137. See supra note 91 and accoinpanying text.

138. 481 F. Supp. 965 (N.D. Cal. 1979), affd, 698 F.2d 1377 (9th Cir.), cert. denied, 104 S. Ct. 370 (1983).

139. See supra note 73 and accompanying text. 
treble damage remedy. ${ }^{140}$ Application of the segregation doctrine may discourage potential plaintiffs incapable of segregating their damage claims froun filing otherwise ineritorious actions. As discussed above, this result is inequitable. Moreover, application of the doctrine inay have the effect of hainpering the private enforcement mechamism in the treble damage remedy, thereby disserving the goals of penalizing and deterring violators of the antitrust laws.

\section{IV}

\section{Alternatives to the Segregation Doctrine}

In an effort to prevent the factfinder froun resorting to speculation in calculating damage awards, courts may feel coinpelled to employ the segregation doctrine despite its mequitable consequences. There are modifications and alternatives to the segregation doctrine, however, that would help the judge or jury avoid making speculative damage awards without barring private plaintiffs from recovery for proven violations and frustrating the purposes of the treble damage action. ${ }^{141}$

140. See generally supra notes 12-20 and accompanying text.

141. Several additional alternatives will not be discussed in detail here, primarily because they have met with little or mixed support in the past. For example, a Presidential commission has considered the use of a special "roster" of judges to handle complex antitrust cases. National Comm'n for the Review of Antitrust Laws and Procedures: Report to the President and the Attorney General, 80 F.R.D. 509, 529 (1979). Judges on such a panel presumably could be relied on to bring greater sophistication to the determination of whether a jury verdict based on plaintiff's lump-sum damage claim was patently unreasonable. However, the Commission concluded that implementation of a special roster of antitrust judges would be unwise because such a plan: (I) would result in unwanted "elitism" among the judiciary; and (2) would provide resources to antitrust cases at the expense of other important cases. Id.

A related alternative would employ special juries in antitrust cases. Several courts have noted that antitrust cases by nature often involve the determination of complex issues that are beyond the abilities of ordinary juries. See, e.g., ILC Peripherals Leasing Corp. v. IBM Corp., 458 F. Supp. 423, 445 (N.D. Cal. 1978) (in striking plaintiff's jury demand in the event of a remand for retrial, the court permitted a complexity exception on the basis of the "practical abilities and limitations" of the jury), affd sub nom. Memorex Corp. v. IBM Corp., 636 F.2d 1188 (9th Cir. 1980), cert. denied, 452 U.S. 972 (1981); see also Jorde, The Seventh Amendment Right to Jury Trial of Antitrust Issues, 69 CALIF. L. Rev. 1, 1-3 \& n.2 (1981). But see MCI Communications Corp. v. AT\&T Co., 708 F.2d 1081, 1175 (7th Cir.) (Wood, J., concurring and dissenting) (jury performed "remarkably well" considering the complexity of the case), cert. denied, 104 S. Ct. 234 (1983); Transamerica Computer Co. v. IBM Corp. (In re IBM Peripleral EDP Devices Antitrust Litig.), 459 F. Supp. 626, 628-29 (N.D. Cal. 1978) (defendant's motion to strike plaintiff's jury demand on the ground that the complex antitrust issues involved in the case were beyond the capabilities of an ordinary jury demied). Under this procedure, the courts would perumt the seating of specifically qualified jurors based on the general "complexity exception," see Ross v. Bernhard, 396 U.S. 531, 538 n.10 (1970), to the seventh amendment right to trial by jury, U.S. CoNST. amend. VII. To qualify to sit on a special jury, the person would have to pass through a special selection procedure designed to test his ability to understand complicated economic and financial data and complex arguments of counsel based on that information. See ILC Peripherals, 458 F. Supp. at 447 (jury foreman suggesting that in this case a qualified jury would need the abilities of a computer technician, a lawyer, and an economist). Objective criteria, such as educational background, see Luneburg \& Nordenberg, Specially Qualified Juries and Expert Nonfury Tribunals: Alternatives for 
While some of these approaches have been considered in other contexts, these alternatives may also be used to achieve the ends of the segregation doctrine.

\section{A. Shifting the Burden of Segregation to the Defendant}

The simplest, most effective alternative would shift the burden of segregating damages to the defendant. Under this approach, a plaintiff would be required to ineet the traditional burdens of proving hability and making a reasonable estimate of its total damages. Then the defendant would have the burden of attributing a specific amount of the plaintiff's lump-sum estimate to each of the alleged violations. Once the defendant had segregated the plaintiff's estimate in this way, the factfinder could delete from its final damage award any element of the lump-sum claim attributable to conduct found to be lawful.

The burden-shifting approach would operate in much the same way as the current segregation doctrine because the damage proof would be allocated among the various alleged unlawful acts prior to the factfinder's determination of the proper amount of damages. In the event the factfinder found some acts to be lawful, it could reduce the award accordingly without resort to speculation. The difference between this approach and the segregation doctrine would be in the risk of failure to segregate the dainage claim. That risk would fall in part on a defendant found liable for at least some violations, rather than solely on the plaintiff that suffered injury froin those violations. Consequently, if a defendant failed to segregate, it would be barred from asserting on motion for judgment notwithstanding the verdict or on appeal that the amount awarded included recovery for both lawful and unlawful conduct. Under the segregation doctrine, in contrast, a plaintiff that failed to segregate would always be barred from recovery in

Coping with the Complexities of Modern Civil Litigation, 67 VA. L. REv. 887, 942-50 (1981), or familiarity with complex antitrust issues, see Jorde, supra, at 3 , might provide the basis for determining the person's suitability to sit on the case. Those persons with relevant advanced training, such as economists and accountants, would be particularly well-suited to special jury service. See generally Lempert, Civil Juries and Complex Cases: Let's Not Rush to Judgment, 80 MICH. L. REv. 68 (1981).

Although the use of special juries could relieve the problem of speculative damage awards to the extent that members of the special jury are peculiarly capable of making exact damage calculations on the basis of a reasonable lump-sum estimate, the constitutionahity of this alternative is questionable under the seventh amendment, see Luneburg \& Nordeuberg, supra, at 899-950, in part at least because the Supreme Court has not ruled specifically on the issue.

Finally, in a trial employing an "ordinary" jury, another alternative would be to refer coinplex issues to a special master in order to resolve factual conflicts for the jury's bcnefit. $M C I$ Communications, 708 F.2d at $1169 \mathrm{n} .125$ (use of a special master suggested on remand to aid in the determination of damages); see Lempert, supra, at 113-15. However, it has been suggested that the master's reports will imterfere with the parties' ability to structure their own cases and that juries might unduly defer to the master's judgment. Id. at 115. 
soine courts, ${ }^{142}$ and in others would be barred unless it proved that segregation was impracticable. ${ }^{143}$

The burden-shifting approach would not violate the rule against shifting the burden of proving dainages because the plaintiff would still have to prove hability and provide a reasonable estimate of its total harm. ${ }^{144}$ In addition, the plaintiff would have to refute the defendant's evidence that the claimed losses resulted from the plaintiff's own mismanagement or froun other factors not arising from the defendant's alleged antitrust violations. The defendant would bear the burden of segregation only if it wished to provide the factfinder with a reasonable basis for allocating dainages among the various alleged anticompetitive acts. It is reasonable to expect that most defendants would try to meet such a burden since their potential liability can be substantial. ${ }^{145}$ The suggested approach therefore places the burden of segregation on the party with the greatest incentive to provide the detailed damage evidence needed to prevent speculation.

Shifting the burden of segregation also accords with the principle that a defendant should not escape the consequences of its wrongs simply because its conduct has made damage calculations difficult. ${ }^{146}$ Viewed in this light, a rule that may force a defendant to pay more damages than it unlawfully caused is still more equitable than one that may deny any recovery to a plaintiff capable of demonstrating soine antitrust injury. Furthermore, defendants nnay not fare less favorably than plaintiffs under a burden-shifting approach. In reducing the damage estimate to coinpensate for conduct found to be lawful, the factfinder may favor the defendant by awarding, prior to trebling, less than the plaintiff's actual damages. The factfinder inay make this kind of award if it becomes sympathetic to the defendant for putting on more specific dainage evidence. Thus this approach nnay spread the risk of uncertain damage calculations ainong both defendants and plaintiffs in a manner consistent with the traditional rule. ${ }^{147}$ The segregation doctrine, in contrast, always forces the plaintiff to bear the risk

142. See supra note 91 .

143. Cf. Multiflex, Inc. v. Samuel Móore \& Co., 709 F.2d 980, $997-99$ (5th Cir. 1983) (holding damage award unsupported by evidence where jury found some conduct lawful and attempted to reduce lump sum estimate accordingly); $\mathrm{MCI}$ Communications Corp. v. AT\&T Co., 708 F.2d 1081, 1160-68 (7th Cir.), cert. denied, 104 S. Ct. 234 (1983) (award of 600 million dollars set aside and case remanded for proper determination of damages because jury awarded lump-sum damages for both lawful and unlawful conduct).

144. Locklin v. Day-Glo Color Corp., 429 F.2d 873, 879 (7th Cir. 1970), cert. denied, 400 U.S. 1020 (1971); see also Associated Press v. Taft-Ingalls Corp., 340 F.2d 753, 769 (6th Cir.), cert. denied, 382 U.S. 820 (1965).

145. See supra note 11 and accompanying text.

146. See supra note 131 and accompanying text.

147. See supra note 132 and accompanying text. 
of uncertainty which the defendant has created through its unlawful conduct.

Finally, shifting the burden of segregation to the defendant can be compared to the principle that once the plaintiff has led the factfinder to infer that the defendant violated the antitrust laws, it is fair to impose on the defendant the burden of overcoming that inference. ${ }^{148}$ Similarly, by proving solne violations and providing a reasonable estiinate of total damages, a plaintiff leads the factfinder to the inference that all of its damages are the result of the defendant's violations. It inay be fair then to require the defendant to explain away that inference by proving that its violations caused only a portion of the total damages claimed.

\section{B. Bifurcation and Direct Judicial Controls}

There are several other approaches to the speculation problem that would yield inore equitable results than application of the segregation doctrine. While these alternatives nnay not address the inequities of the doctrine as directly and completely as shifting the burden of segregation to the defendant, they nevertheless respond to the concerns that moved the courts to require segregation. Moreover, courts may be less averse to using these alternatives in treble damage actions because they are occasionally used in other trials.

\section{Bifurcation}

One alternative would require the court to bifurcate a treble damage action involving multiple alleged antitrnst violations into separate proceedings on hability and damages. ${ }^{149}$ In the first part of the trial, the plaintiff would attempt to estabhish the defendant's hability for the various alleged violations. The factfinder would then determine the defendant's hability, specifying which alleged conduct was actually un-

148. William Goldman Theatres, Inc. v. Loew's, Inc., 150 F.2d 738, 743 (3d Cir. 1945).

149. This procedure has been used on a number of occasions. E.g., French Quarter Apartments, Ltd. v. Georgia-Pacific Corp. (In re Plywood Antitrust Litig.), 655 F.2d 627, 636 (5th Cir. 1981); Berkey Photo, Inc. v. Eastman Kodak Co., 603 F.2d 263, 268 (2d Cir. 1979), cert. denied, 444 U.S. 1093 (1980); Northeastern Tel. Co. v. AT\&T Co., 497 F. Supp. 230, 234 (D. Conn. 1980), rev'd in part and vacated in part, 651 F.2d 76 (2d Cir. 1981), cert. denied, 455 U.S. 943 (1982); In re Ampicillin Antitrust Litig., 88 F.R.D. 174, $178-79$ (D.D.C. 1980); $f f$. In re Corrugated Contamer Antitrust Litig., 1980-81 Trade Cas. (CCH) \ 63,669 (S.D. Tex. 1980) (jury permitted to determine liability and measure of damage, with exact dollar amounts of damage to be determined later). But see Multiflex, Inc. v. Samuel Moore \& Co., 709 F.2d 980, 998-99 (Sth Cir. 1983) (bifurcation ordered on remand for proper determination of damages where jury awarded lump-sum damages for both lawful and unlawful conduct); MCI Communications Corp. v. AT\&T Co., 708 F.2d 1081, 1166-69 (7th Cir.), cert. denied, 104 S. Ct. 234 (1983) (same). Separate juries may liear each phase of the trial. Gasoline Prods. Co. v. Champlin Ref. Co., 283 U.S. 494 (1931). 
lawful. ${ }^{150}$ In the second part of the trial, the plaintiff would submit a damage claim based only on those acts previously found to be unlawful. Evidence of damage resulting from the defendant's lawful competition or the plaintiff's own inefficiency would be barred in the second part of the trial. In cases where the plaintiff was unable to establish any hability in the first proceeding, a second proceeding to determine the amount of damage would be unnecessary.

Both the plaintiff and the defendant would benefit from bifurcation of the treble damage action. Prior to both proceedings each party would still have to prepare for trial on all issues raised by the pleadings. However, if the plaintiff failed to establish its right to recover on all its claims of injury, the issue of damages in the second trial would be significantly narrowed because the plaintiff would only be alleging an amount based on antitrust injuries already proved. Thus the opportunities for jury speculation would be limited. ${ }^{151}$

Rule 42(b) of the Federal Rules of Civil Procedure ${ }^{152}$ permits bifurcation whenever separate trials would be either useful "in furtherance of convenience or to avoid prejudice, or ... conducive to expedition and economy .....153 Courts may order separate proceedings simply on the ground that bifurcation would force the plaintiff to structure its damage evidence in the second phase according to the findings of liability made in the first phase. ${ }^{154}$ Similarly, simplification of the factual presentation, minimization of the amount of time necessary to decide the whole case, and reduction in the cost of the suit to the parties and the court are appropriate reasons for ordering separate trials. ${ }^{155}$

150. J. Truett Payne Co. v. Chrysler Motors Corp., 451 U.S. 557 (1981) (finding of liability must precede ruling on amount of damage).

151. It might be argued that bifurcation is not needed to prevent jury speculation because jury deliberations can be adequately controlled by means of proper instructions to the jury on its duty to render a damage verdict based solely on the acts which the jury finds to be unlawful. In fact, courts often instruct juries to award only compensatory damages in treble damage actions. See Note, Controlling Jury Damage Awards in Private Antitrust Suits, 81 Mich. L. Rev. 693, 708 (1983). However, jury instructions may not prevent the jury from mixing losses based on lawful conduct with those based on unlawful conduct, once the jury has heard evidence on both. Bifurcation, im contrast, would permit the jury in the second phase to hear only the evidence of damage from proven violations.

152. FED. R. CIV. P. 42(b).

153. Id.; see United States v. IBM Corp., 60 F.R.D. 654, 655 (S.D.N.Y. 1973) (only one of these conditions nust be met for the court to order bifurcation).

154. See Manual for Complex Litigation $\$ 4.12$ (5th ed. 1981).

155. See MCI Communications Corp. v. AT\&T Co., 708 F.2d 1081, 1167 (7th Cir.) (citing Schwartz, Severance-A Means of Minimizing the Role of Burden and Expense in Determining the Outcome of Litigation, 20 VAND. L. Rev. 1197 (1967); Zeisel \& Callahan, Split Trials and Time Saving: A Statistical Analysis, 76 Harv. L. Rev. 1606 (1963); Miner, Court Congestion: A New Approach, 45 A.B.A. J. 1265 (1959); Note, Original Separate Trials on Issues of Damages and Liability, 48 VA. L. REv. 99 (1962); Note, Separate Trial of a Claim or Issue in Modern Pleading: 


\section{Direct Judicial Controls}

The courts adopting the segregation doctrine have expressed great concern about preventing "speculation" in the award of treble damages. The courts' unore particular concern, however, is that ordinary jurors, unskilled in evaluating the complex economic and financial data submitted in support of treble damage claims, ${ }^{156}$ will render speculative damage verdicts that lack a reasonable basis in fact unless they are provided segregated claims.

Several approaches that give judges greater control over the jury's determination of dainages can solve this problem by ensuring that the jury makes a reasoned calculation. In contrast, the segregation doctrine appears to give judges complete discretion to bar a plaintiff from recovering as a inatter of law, without even giving the jury the opportunity to determine whether the plaintiff could prove antitrust injury.

\section{a. Discretionary Trebling}

A grant of judicial discretion to treble would require an amendment to section 4 of the Clayton Act. ${ }^{157}$ The language of that section currently provides that "any person ... injured in his business or property by reason of anything forbidden in the antitrust laws . . . shall recover threefold the damages by him sustamed."158 Although Congress has previously rejected several proposals to make the treble daniage award discretionary or to provide for single or double damages, ${ }^{159}$ the segregation doctrine may revive legislative interest in an amendinent because of the manner in which the doctrine underninines congressional intent to provide for treble danıage actions. ${ }^{160}$

The nature of the alleged antitrust violation could forn the basis for the degree of judicial discretion afforded by an amended section $4 .^{161}$ For example, if a defendant were held hable for conduct that

Rule 42(b) of the Federal Rules of Civil Procedure, 39 MiNN. L. REv. 743 (1955)), cert. denied, 104 S. Ct. 234 (1983).

156. See supra note 141.

157. It has been suggested, however, that $\S 4$ may be interpreted to permit discretionary trebling by "implied qualifications 1 ) in infrequent situations not within the contemplation of those who wrote the statute and 2) where qualification would best serve both the fundamental purposes of the statute and the ends of justice." 2 P. AREEDA \& D. TURNER, supra note 4, $\{331 \mathrm{b3}$, at 151.

158. 15 U.S.C. \& 15 (1982) (emphasis added).

159. Congress has had several opportunities to consider this issue, and has refused to reduce or eliminate the remedy. It also refused to give the courts the discretion to reduce the damage award below the trebled amount. See K. Elzinga \& W. Breit, The Antitrust Penalties: A STUDY IN LAW AND ECONOMICs 64-65 (1976) (cited in Note, supra note 151, at 703 n.48).

160. See supra notes $12-20$ and accompanying text.

161. The Reagan Administration proposed to amend $\S 4$ to provide for single damages in antitrust cases, except that "damages attributable to agreements or practices the nature or necessary effect of which is so plainly anticompetitive that they are deemed unreasonable and therefore illegal without elaborate study in each individual case as to the precise harm they have caused or 
is anticompetitive per se ${ }^{162}$ such as engaging in a price-fixing conspiracy, ${ }^{163}$ the judge might be required to award treble damages regardless of whether the plaintiff's damage proof was segregated. Thus as long as the plaintiff provided a reasonable estimate of the total amount of harm it suffered, it could recover treble damages because of the seriousness of the defendant's violation. On the other hand, when a judge applies a rule of reason ${ }^{164}$ analysis, such as to an allegation that the defendant entered into an illegal merger, ${ }^{165}$ the judge might be granted the discretion to award single or treble damages, depending on the specificity of the plaintiff's damage evidence. The judge might permit a plaintiff providing segregated estimates of its damage to recover treble damages, while limiting a plaintiff capable at best of proving a reasonable estimate of its total harm to recovery of single damages.

A provision for discretionary trebling would serve the purposes of the treble damage remedy while eliminating any inequities resulting from jury speculation. ${ }^{166}$ First, it would fulfill the goal of redressing

the business justification for their use shall be trebled." 44 ANTITRUST \& TRADE REg. REP. (BNA) No. 1108, at 713 (March 31, 1983). For a criticism of the Reagan proposal and a suggested variation, see Baker, supra note 20 , at 20 , col. 1 . The proposal in this Comment is based substantially on the Baker alternative.

162. The broad language of the antitrust statutes provides wide latitude for judicial interpretation. Generally, the courts have applied a rule of reason, see infra note 164, to determine whether defendant unduly restrained coinpetition. L. Sullivan, supra note 17, § 72, at 195-96. However, the courts have held that a per se violation of the antitrust laws results when plaintiff proves that defendant engaged in a practice so clearly anticoinpetitive that the public could not be expected to benefit in any way. See Northern Pac. Ry. v. United States, 356 U.S. 1, 5 (1958); L. Sullivan, supra note $17, \S 72$, at 196.

Price fixing is the offense inost clearly held to constitute a per se violation. See, e.g., United States v. Socony-Vacuum Oil Co., 310 U.S. 150 (1940); United States v. Trenton Potteries Co., 273 U.S. 392 (1927). However, other offenses held to be per se violations include boycotts, e.g. Radiant Burners, Inc. v. Peoples Gas Light \& Coke Co., 364 U.S. 656 (1961); Klor's, Inc. v. BroadwayHale Stores, Inc., 359 U.S. 207 (1959), allocation of custoiners or territories ainong coinpetitors, e.g., Northern Pac. Ry. v. United States, 356 U.S. 1 (1958), and tying arrangements, id.

On the historical development of the rule of reason and the per se doctrine, see L. SulLIVAN, supra note $17, \S \S 63-72$, at $165-97$.

163. E.g., Northern Pac. Ry. v. United States, 356 U.S. 1 (1958).

164. Rule of reason analysis focuses on whether the alleged anticompetitive practice was "unreasonably restrictive of competitive conditions." National Soc'y of Professional Eng'rs v. United States, 435 U.S. 679, 690 (1978). Under this test,

Unreasonableness . . . could be based either 1) on the nature or character of the contracts, or 2) on surrounding circumstances giving rise to the inference or presumption that they were intended to restrain trade and enhance prices. Under either branch of the test, the inquiry is confined to a consideration of impact on competitive conditions.

Id. (footnote omitted). Consideration of the effect of the alleged offense on competition has traditionally been the hallmark of such analysis. E.g., United States v. E.I. du Pont de Nemours \& Co., 351 U.S. 377 (1956); Board of Trade of Chicago v. United States, 246 U.S. 231 (1918); Standard Oil Co. v. United States, 221 U.S. 1 (1911).

165. E.g., Brown Shoe Co. v. United States, 370 U.S. 294 (1962).

166. See 3 P. AREEDA \& D. TuRNER, supra note 4, $\$ 630 c$, at 97 . Noting that treble damages are inherently punitive, the authors argue that this remedy is inappropriate where "the liability determination rests on close and uncertain economic factual determinations." Id. 
private grievances by ensuring that all injured plaintiffs recover at least their actual damages. Second, it would encourage private enforcement of the antitrust laws because private plaintiffs, required at most to provide a reasonable estimate of their total harm, would not be deterred froin filing ineritorious claims. Third, a discretionary trebling provision would limit the impact of jury speculation by predicating the extent of defendants' liability in rule of reason cases on plamtiffs' ability to develop specific damage evidence. If a plaimtiff were unable to segregate its damage claim, its recovery would vary proportionately with the egregiousness of the defendant's violation, thus serving the goals of pumshment and deterrence.

\section{b. Remittitur}

Courts could also control jury speculation by inore frequently ordering remittitur of the dainage award prior to trebling. ${ }^{167}$ Thus if a damage award was clearly erroneous im light of the evidence, ${ }^{168}$ the judge could set the damages at the highest level that was not clearly erroneous ${ }^{169}$ and order a new trial unless the plaintiff consented to the lower award.

Remittitur would be especially appropriate in cases where the plaintiff was unable to obtain precise damage evidence to satisfy the segregation doctrine. ${ }^{170}$ In those cases, the court could perinit the plaintiff to proceed with a lump-suin damage claim on the express condition that the judge would reduce the jury's award if it was excessive. Although the plaintiff would face the risk of remittitur if it did not adequately segregate the damage claim, it would not be demied recovery for proven violations merely because it submitted imprecise damage evidence. ${ }^{171}$

167. Remittitur has been held consistent with the seventh amendment right to jury trial. Northern Pac. Ry. v. Herbert, 116 U.S. 642, 646-47 (1886). In contrast, the seventh amendment forbids the practice of additur in federal courts. Dimick v. Schiedt, 293 U.S. 474 (1935).

168. See, e.g., Multiflex, Inc. v. Samuel Moore \& Co., 709 F.2d 980, 998 (5th Cir. 1983); Spray-Rite Serv. Corp. v. Monsanto Co., 684 F.2d 1226, 1242-44 (7th Cir. 1982), affd on other grounds, 52 U.S.L.W. 4341 (U.S March 20, 1984).

169. See International Paper Co. v. Busby, 182 F.2d 790, 793 (5th Cir. 1950).

170. See Northeastern Tel. Co. v. AT\&T Co., 497 F. Supp. 230, 248 (D. Conn. 1980), rev'd in part and vacated in part, 651 F.2d 76 (2d Cir. 1981), cert. denied, 455 U.S. 943 (1982).

171. It is conceivable that one reason judges might turn to the segregation doctrine is to avoid the ever-increasing size of treble damage awards. See Comments of Maxwell M. Blecher in Panel Discussion: An Overview of Antitrust Compliance, Correction and Containment, 48 ANTITRust L.J. 219,230 (1979). Increased use of remittitur could help counteract these fears. Rather than barring the plaintiff froin recovery, as the segregation doctrine might require, the court could merely inake what it considered an appropriate reduction in the award. Although the jury verdict may award plaintiff a cousiderable amount of damages, see supra note 11, the mere size of the verdict should not prevent recovery altogether where the jury's calculation was based on a reasonable evidentiary foundation. See Richfield Oil Corp. v. Karseal Corp., 271 F.2d 709 (9th Cir. 1959), cert. denied, 


\section{c. Special Verdicts and General Verdicts Accompanied by Answers to Interrogatories}

Finally, the courts could control jury speculation by requiring the jury to render special verdicts or a general verdict accompanied by answers to interrogatories. ${ }^{172}$ Special verdicts require the jury to give written answers to questions about specific factual issues in the case. ${ }^{173}$ The judge then decides as a matter of law which party will prevail on the basis of the jury's findings of fact. Similarly, a general verdict accompanied by answers to imterrogatories requires the jury to answer written questions of fact submitted by the judge. Use of this procedure, however, allows the jury to return a damage verdict of its own. ${ }^{174}$

Either of these procedures would prevent the jury from rendering a speculative lump-sum damage verdict because the jury would be required to make specific factual findings on each issue of damages. If the jury found that the plamtiff had not been injured by a particular antitrust violation, the court or the jury, depending on the procedure used, could reduce the damage verdict accordingly. While this process of arriving at a reduced damage figure might still be somewhat inexact, it would avoid the undue hardship imposed by the segregation rule. Moreover, judicial review of the case would be simplified because the appellate court would have a written record of the damage evidence rehed on by the jury to support its findings of fact or damage award. Thus retrial of the whole case would not be necessary if the appellate court reversed only one element of the damage award. ${ }^{175}$

361 U.S. 961 (1960); Bray v. Safeway Stores, Inc., 392 F. Supp. 851, 864 (N.D. Cal.), case dismissed on other grounds, 403 F. Supp. 412 (N.D. Cal. 1975).

172. Rule 49 of the Federal Rules of Civil Procedure permits a court, at its discretion, to use either of these procedures. FED. R. CIv. P. 49. One court has stated that the use of these procedures was to be preferred over bifurcation of the trial into separate proceedings on hability and damages. Berkey Photo, Inc. v. Eastman Kodak Co., 603 F.2d 263, 279 (2d Cir. 1979), cert. denied, 444 U.S. 1093 (1980).

173. The judge must give the jury sufficient explanations to enable it to inake a finding on each issue it has been given. FED. R. Crv. P. 49(a). However, the jury ordinarily is not instructed on the legal consequences of the factual issues it is asked to resolve. See Thedorf v. Lipsey, 237 F.2d 190, 193 (7th Cir. 1956). But see Lowery v. Clouse, 348 F.2d 252, 260-61 (8th Cir. 1965) (jury may be informed of the legal effects of its findings).

174. FED. R. Clv. P. 49(b). When the general verdict and the answers to interrogatories are consistent, the court orders judginent upon the verdict. $I d$. Special procedures are provided, however, if the answers to interrogatories are inconsistent. If the answers are internally consistent but one or more is incousistent with the general verdict, the court may order judgment n.o.v. in accordance with the answers, pursuant to Rule 58, FED. R. Civ. P. 58, or the court may return the jury for further consideration of its answers or order a new trial. FED. R. CIv. P. 49(b). If the answers are internally inconsistent and one or more of the answers is also imcousistent with the general verdict, the court will return the jury for further consideration of its answers and verdict or order a new trial. $I d$.

175. See MCI Commumications Corp. v. AT\&T Co., 708 F.2d 1081 (7th Cir.), cert. denied, 


\section{CONCLUSION}

The emergence of the segregation doctrine threatens to restrict substantially the right of private plaintiffs to recover treble damages under section 4 of the Clayton Act. The doctrine, which provides that a plaintiff inust allocate to each claim of injury a specific ainount of dainage, was designed to prevent speculative dainage awards in cases involving multiple alleged antitrust violations. This Comment has argued that, if applied literally, the segregation doctrine will undermine the purposes of the private antitrust action by barring recovery when plaintiffs lack precise damage proof and by weakening the private enforcement mechanism inherent in the treble damage remedy. Moreover, there are modifications and alternative approaches to the doctrime that can prevent speculative damage awards while fulfilling the goals of the treble daniage remedy.

Charles N. Charnas*

104 S. Ct. 234 (1983) (partial retrial necessary because interrogatories accompanying general verdict form only asked for lump-sum damage answer).

* A.B. 1981, Stanford University; third-year student, Boalt Hall School of Law, University of Califorma, Berkeley. 